\title{
Flora of Pernambuco, Brazil: Tabebuia alliance and tribe Jacarandeae (Bignoniaceae)
}

\author{
Swami Costa $^{1 *}$, Lúcia G. Lohmann ${ }^{2} \mathbb{D}$ \& Maria Teresa Buril ${ }^{1}(\mathbb{D}$ \\ ${ }^{1}$ Universidade Federal Rural de Pernambuco, Departamento de Botânica, Recife, PE, Brasil. \\ ${ }^{2}$ Universidade de São Paulo, Instituto de Biociências, Departamento de Botânica, São Paulo, SP, Brasil. \\ *Corresponding author: Swami Costa, e-mail: swamilcosta@hotmail.com
}

COSTA, S.; LOHMANN, L.G.; BURIL, M.T. Flora of Pernambuco, Brazil: Tabebuia alliance and tribe Jacarandeae (Bignoniaceae). Biota Neotropica. 19(4): e20190737. http://dx.doi.org/10.1590/1676-0611-BN-2019-0737

\begin{abstract}
Bignoniaceae is a Pantropical plant family that includes 82 genera and 830 species of trees, lianas, and shrubs. The Tabebuia alliance (14 genera and 147 species) and tribe Jacarandeae ( 2 genera and 50 species) are both Neotropical and represent the largest clades of trees and shrubs in the family. Here, we present a taxonomic treatment for these two clades for the state of Pernambuco, Brazil. Overall, we documented 23 species distributed in seven genera, i.e., Cybistax Mart. ex Meisn., Godmania Hemsl., Jacaranda Juss., Handroanthus Mattos, Sparattosperma Mart. ex Meisner, Tabebuia Gomes ex DC., and Zeyheria Mart. Six taxa are new records for the state, i.e., Cybistax antisyphilitica (Mart.) Mart., Handroanthus capitatus (Bureau \& K. Schum) Mattos, Handroanthus umbellatus (Sond.) Mattos, Jacaranda cuspidifolia Mart., Sparattosperma catingae A.H. Gentry, and Tabebuia stenocalyx Sprague \& Stapf. Furthermore, S. catingae, previously thought to be endemic to the Caatinga of Bahia, was documented for the first time in the Atlantic Forest domain. We present identification keys and taxonomic descriptions for all genera and species, as well as provide illustrations and information on the geographic distribution, habitat, and phenology for all species.
\end{abstract}

Keywords: Botanical inventories; Brazilian flora; Caatinga; Atlantic Forest.

\section{Flora de Pernambuco, Brasil: Aliança Tabebuia e tribo Jacarandeae (Bignoniaceae)}

\begin{abstract}
Resumo: Bignoniaceae é uma família de plantas pantropicais que inclui 82 gêneros e 830 espécies de árvores, lianas e arbustos. A aliança Tabebuia (14 gêneros e 147 espécies) e tribo Jacarandeae (2 gêneros e 50 espécies) são ambas neotropicais e representam os maiores clados de árvores e arbustos na família. Aqui, apresentamos um tratamento taxonômico para estes dois clados para o estado de Pernambuco, Brasil. No geral, nós documentamos 23 espécies distribuídas em 7 gêneros, i.e., Cybistax Mart. ex Meisn., Godmania Hemsl., Jacaranda Juss., Handroanthus Mattos, Sparattosperma Mart. ex Meisner, Tabebuia Gomes ex DC., e Zeyheria Mart. Seis táxons são novos registros para o estado, i.e., Cybistax antisyphilitica (Mart.) Mart., Handroanthus capitatus (Bureau \& K. Schum) Mattos, Handroanthus umbellatus (Sond.) Mattos, Jacaranda cuspidifolia Mart., Sparattosperma catingae A.H. Gentry, e Tabebuia stenocalyx Sprague \& Stapf. Além disso, S. catingae, que anteriormente se pensava ser endêmica da Caatinga da Bahia, foi documentada pela primeira vez no domínio da Mata Atlântica. Nós apresentamos chaves de identificação e descrições taxonômicas para todos os gêneros e espécies, assim como fornecemos ilustrações e informações sobre a distribuição geográfica, habitat e fenologia para todas as espécies.
\end{abstract}

Palavras-chave: Inventários botânicos; Flora brasileira; Caatinga; Mata Atlântica.

\section{Introduction}

The Bignoniaceae comprises about 830 species distributed in 82 genera (Lohmann \& Ulloa Ulloa 2006 continuously updated). This plant family is Pantropical, but predominantly Neotropical, where about $80 \%$ of the species occur, with only a few species occurring in the Temperate zones (Lohmann 2004). The Bignoniaceae is centered in Brazil, where 33 genera and 413 species are found, of which two genera (Neojobertia Baill. and Paratecoma Kuhlm.) and 199 species are endemic (Lohmann 2010). The family includes lianas, trees, and shrubs that generally occur in humid or dry forests, sometimes in open dry areas, or rocky outcrops (Lohmann 2004).
Members of the family are characterized by the following synapomorphies: a lack of endosperm in the mature seeds, and by two placental ridges, each bearing one to several rows of ovules (Spangler $\&$ Olmstead 1999). Species of the Bignoniaceae are also recognized by the woody habitat, opposite and compound leaves, showy hermaphrodite and gamopetalous flowers, with four didynamous stamens and one staminode (reduced or elongated), and dehiscent fruits with winged seeds (Lohmann 2004).

Gentry (1980) divided the family into eight tribes based on habit, distribution and fruit dehiscence: Bignonieae, Coleeae, Crescentieae, Eccremocarpeae, Oroxyleae, Schlegelieae, Tecomeae, and Tourrettieae. 
Subsequent phylogenetic studies (Spangler \& Olmstead 1999, Olmstead et al. 2009) indicated that Tecomeae is not monophyletic and that the supra-generic classification needed to be reformulated. Six monophyletic tribes (i.e., Bignonieae, Catalpeae, Jacarandeae, Oroxyleae, Tecomeae, and Tourrettieae) and two informally named clades (i.e., Tabebuia alliance and Paleotropical clade) are currently recognized (Olmstead et al. 2009).

The Tabebuia alliance is restricted to the Neotropics and includes 14 genera and 147 species, representing the second largest clade of the family (Olmstead et al. 2009). The clade includes genera composed predominantly of large trees such as Handroanthus Mattos and Tabebuia Gomes ex DC., as well as treelets and shrubs (Olmstead et al. 2009). Taxa included in this clade are characterized by the palmate-compound leaves (synapomorphy of the clade), flowers with spathaceous to cupular calyces, and infundibuliform corollas with varied colors, and linear to ovate ovaries (Grose \& Olmstead 2007, Olmstead et al. 2009). In Brazil, this group is represented by seven genera and 44 species (Handroanthus, Tabebuia, Zeyheria Mart., Godmania Hemsl., Paratecoma Kuhlm., Cybistax Mart ex Meisn. and Sparattosperma Mart. ex Meisner) most of which are broadly distributed throughout the national territory, except from Paratecoma and Godmania that have more restricted distributions (Lohmann 2010).

Tribe Jacarandeae includes two genera (Jacaranda Juss. and Digomphia Benth.), and around 55 species distributed from Guatemala to Argentina (Olmstead et al. 2009). Both genera and 38 species are found in Brazil (Lohmann 2010). This clade is sister to the rest of the family and easily distinguished by the elongated and glandular staminodes, pinnately or bipinnately compound leaves, calyx with deeply divided lobes, and oblong to elliptic flattened woody capsules that dehisce perpendicularly to the septum (Olmstead et al. 2009).

The Northeast of Brazil concentrates around 215 species, representing one of the regions with the greatest diversity of Bignoniaceae within the country (Lohmann 2010). The state of Pernambuco comprises 60 of the 215 species found in the region (Lohmann 2010). However, there is still little information about the family in Northeastern Brazil, especially in the state of Pernambuco. The objective of this work is to inventory all members of the Tabebuia alliance and tribe Jacarandeae in the state of Pernambuco (Northeastern Brazil), and present a taxonomic treatment for all taxa. Our findings will help reduce the taxonomic impediment and contribute knowledge that is relevant for the conservation of the Brazilian flora. This study provides useful information for future studies on the ecology, evolution, and biogeography of this iconic group of Brazilian plants.

\section{Material and Methods}

Pernambuco is located in Northeastern Brazil (Figure 1), being limited in the south by the states of Alagoas and Bahia, in the north by the states of Ceará and Paraíba, and in the west by the state of Piauí.

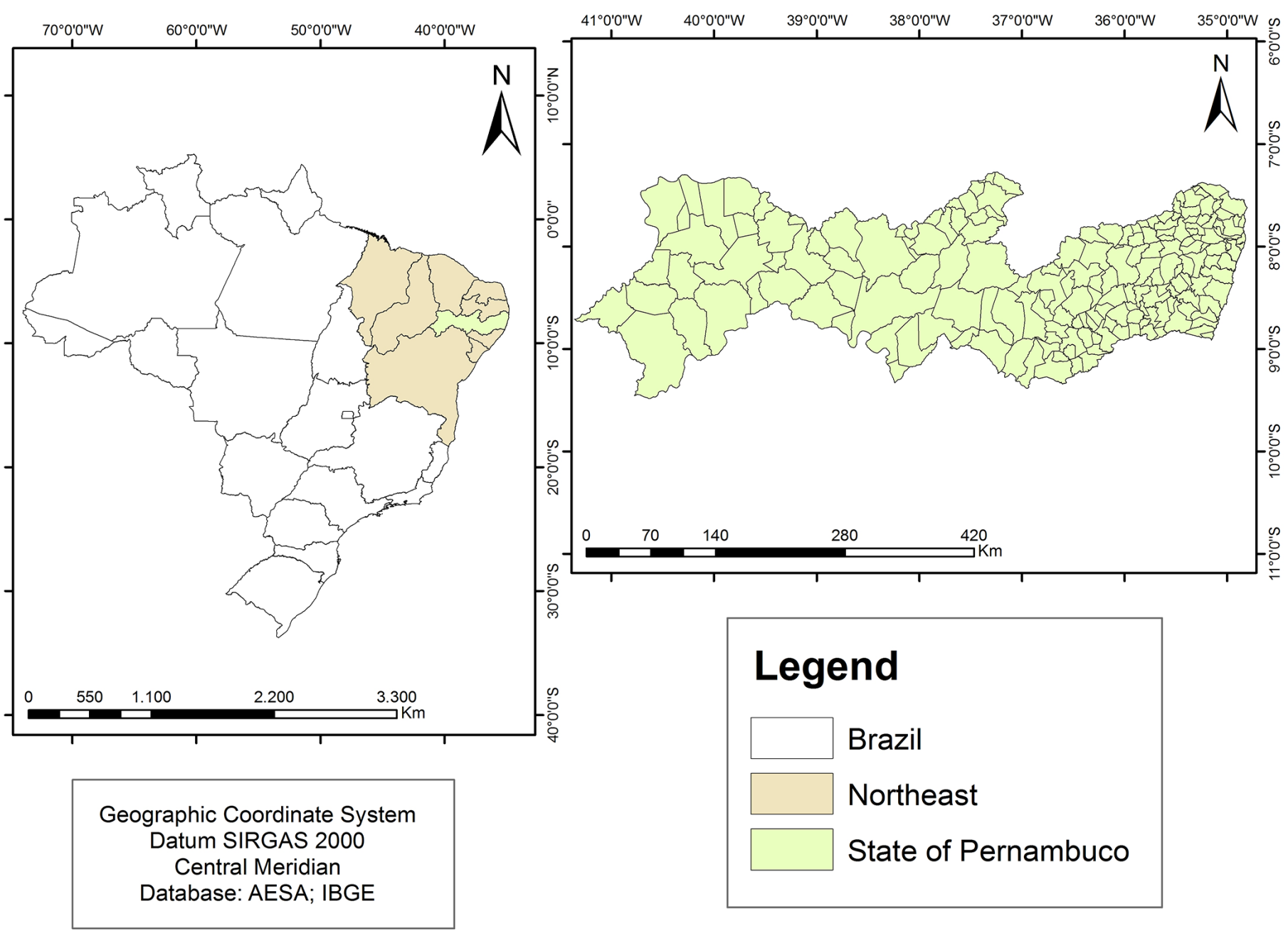

Figure 1. Map indicating the location of the state of Pernambuco (in light green), within the Northeastern region of Brazil (in orange). Prepared by Thais Mara Souza. 
Pernambuco is situated between $7^{\circ} 15^{\prime} 45^{\prime \prime}$ and $9^{\circ} 28^{\prime} 18^{\prime \prime} \mathrm{S}$, and between $34^{\circ} 48^{\prime} 35^{\prime \prime}$ and $41^{\circ} 19^{\prime} 54^{\prime \prime} \mathrm{W}$, including $98.311 \mathrm{~km}^{2}$ of surface area (Andrade-Lima 1960). The state includes heterogeneous climate, soil, and phytophysiognomies, although the regions with semi-arid climate, covered with Caatinga vegetation occupy around $80 \%$ of the state. Fragments of ombrophilous and seasonal forests, forested highlands, restingas, mangroves, dunes and associated ecosystems are available in the coastal areas and "Zona da Mata" (Andrade-Lima 1960).

Field trips were carried out between 2017 and 2018 to collect and observe living material, as well as to obtain data on the ecological characteristics of the individual species. The timing of field trips was defined according to the species phenological data obtained from herbarium collections and literature. In the field, collection and herborization procedures followed Bridson \& Forman (1998). Specimens were deposited in the PEUFR herbarium. In addition to the materials collected in the field, materials deposited at thirteen herbaria located in the state of Pernambuco were analyzed, i.e., ACAM, EAC, HESBRA, HST, HUEFS, HUFRN, HVASF, IPA, JPB, MOSS, PEUFR, $\mathrm{RB}$ and UFP (herbarium acronyms follow Thiers, continuously updated).

Specimen identification was based on comparisons with specimens previously identified by specialists, images of Type materials, species protologues, and published taxonomic treatments and floristic inventories (e.g., Bureau \& Schumann 1896, Espirito-Santo et al. 2014, Gentry 1992 ,
2009, Lohmann 2004, 2010, Lohmann \& Pirani 1996a, 1996b, 2003, Pereira \& Mansano 2008, Scudeller 2004, Silva-Castro et al. 2007). We also consulted online collections of the Virtual Herbarium REFLORA (Brazil), Missouri Botanical Garden (MOBOT), and The New York Botanical Garden (NY) to support identifications and complement information on the species distribution and morphology.

Morphological descriptions were based on materials collected in the field and those deposited in herbaria. Descriptions follow the terminology of Harris \& Harris (2000) and Gonçalves \& Lorenzi (2007) and focus on diagnostic reproductive and vegetative traits. Due to the large amount of examined materials, we selected the best quality fertile specimens from each phytogeographic domain (Caatinga and/or Atlantic Forest) and list those as "selected material." The remaining specimens analyzed are included in an overall list of examined specimens (Appendix 1). Information on the geographic distribution, flowering and fruiting periods, ecological preferences, altitude, and common names were obtained from specimen labels. Ornamental species are not included.

The map of the region (Figure 1) and the species richness maps (Figure 2) were both prepared using DIVA-GIS, while figure captions were prepared in Corel Draw X7. The coordinates were obtained through field collections and original coordinates indicated in specimen labels or using speciesLink.

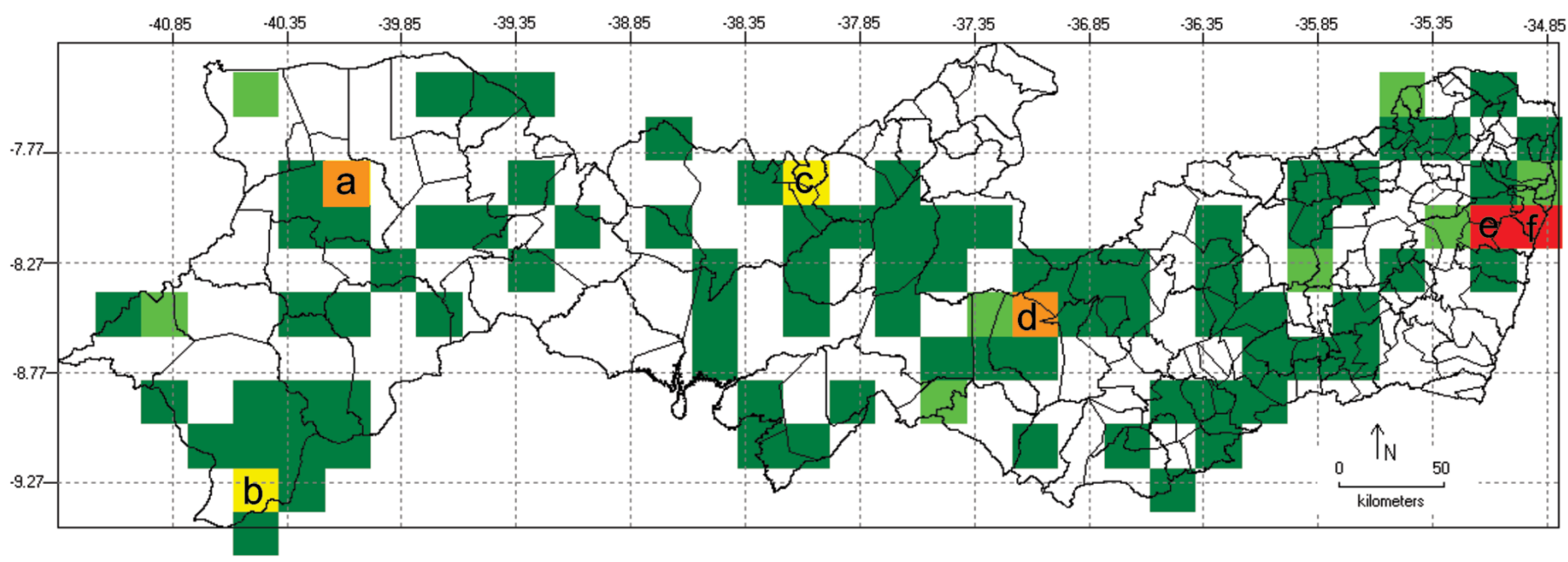

Number of species:

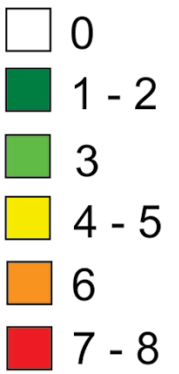

Richest areas:

$$
\begin{aligned}
& \text { a - National Forest Negreiros } \\
& \text { b - Petrolina } \\
& \text { c - Triunfo } \\
& \text { d - National Park Vale do Catimbau } \\
& \text { e - Ecological Reserve Carnijó } \\
& \text { f - State Park Dois Irmãos }
\end{aligned}
$$

Figure 2. Map showing the species richness of members of the Tabebuia alliance and tribe Jacarandeae in the state of Pernambuco. Prepared by Silmara Nepomuceno. 


\section{Taxonomic treatment}

Identification key for the Tabebuia alliance and Jacarandeae genera occurring in the state of Pernambuco

1. Leaves pinnate or bipinnate; staminode longer than fertile stamens, covered by glandular trichomes Jacaranda 1 '. Leaves simple or palmate; staminode shorter than fertile stamens, glabrous

2. Calyx tubular, densely lepidote to glabrous

3. Leaflets discolorous; inflorescences in thyrse; corolla white to light pink Sparattosperma

3'. Leaflets concolorous; inflorescences in panicle; corolla yellow or white Tabebuia

2'. Calyx cupular, pubescent or tomentose

4. Corolla infundibuliform

5. Calyx membranaceous; corolla green; capsules elliptic to oblong, ribbed ............................................ Cybistax 5'. Calyx coriaceous; corolla yellow, pink, lilac or purple; capsules linear-cylindrical, not-ribbed .............. Handroanthus 4'. Corolla campanulate or urceolate

6. Calyx green, with simple trichomes; corolla cream externally, with purple spots internally; capsules linear-twisted, smooth ..

Godmania

6'. Calyx dark brown, with stellate trichomes; corolla brown externally, orange internally; capsules wide-elliptic, muricate

Zeyheria

Cybistax Martius ex Meisner, Pl. vasc. gen. 2: 208, 1840.

Cybistax is a monospecific genus, represented in the state of Pernambuco by Cybistax antisyphilitica.

1. Cybistax antisyphilitica (Mart.) Mart., Syst. Mat. Med. Bras., 66, 1843. Figure 3 a-e.

Tree; branchlets cylindrical, striated, without lenticels, glabrous. Leaves palmate, 5-6 foliolate; petiole $6.1-16 \mathrm{~cm}$ long, glabrous; petiolule. $0.4-1.6 \mathrm{~cm}$ long, glabrous; leaflets chartaceous, $11-13.4 \times$ $4.7-5 \mathrm{~cm}$, elliptic to obovate, base cuneate, apex acuminate, margin entire, slightly revolute, concolorous, adaxial surface glabrous, abaxial surface lepidote, with sparse simple trichomes; venation camptodromous. Inflorescence in thyrse, terminal; bracts $0.5-1.5$ cm long, oblanceolated; bracteoles $0.5-0.8 \mathrm{~cm}$ long, oblanceolated to narrow-elliptic. Calyx cupular, membranaceous, 1.1-2.8 $\times 0.5-1.0$ $\mathrm{cm}$, 5-dentate, prolonged acuminate teeth, yellow to green, sparsely pubescent in length and velutinous at apex, with simples trichomes, internally velutinous, with simple trichomes, caducous. Corolla infundibuliform, $2.2-6.8 \times 0.9-1.3 \mathrm{~cm}$, both sides green, externally pubescent, with simple trichomes; stamens included, anthers ca. 0.3 $\mathrm{cm}$ long, glabrous, dorsal filaments $2.2-2.3 \mathrm{~cm}$ long, ventral filaments $1.7-1.9 \mathrm{~cm}$ long, staminode shorter than fertile stamens, ca. $0.2 \mathrm{~cm}$ long; ovary sessile, ovate-oblong, $0.3 \times 0.1 \mathrm{~cm}$, lepidote, style ca. $2.7 \mathrm{~cm}$ long, stigma ca. $0.2 \mathrm{~cm}$ long, lanceolate. Capsule $15.3 \times 4.2 \mathrm{~cm}$, elliptic to oblong, longitudinally 12 -ribbed, prominent ribs, base and apex acuminate, glabrous surface, woody, slightly inflated. Seeds winged, $0.6-1.5 \times 0.7-1.8 \mathrm{~cm}$, wide-elliptic, wings hyaline, membranaceous.

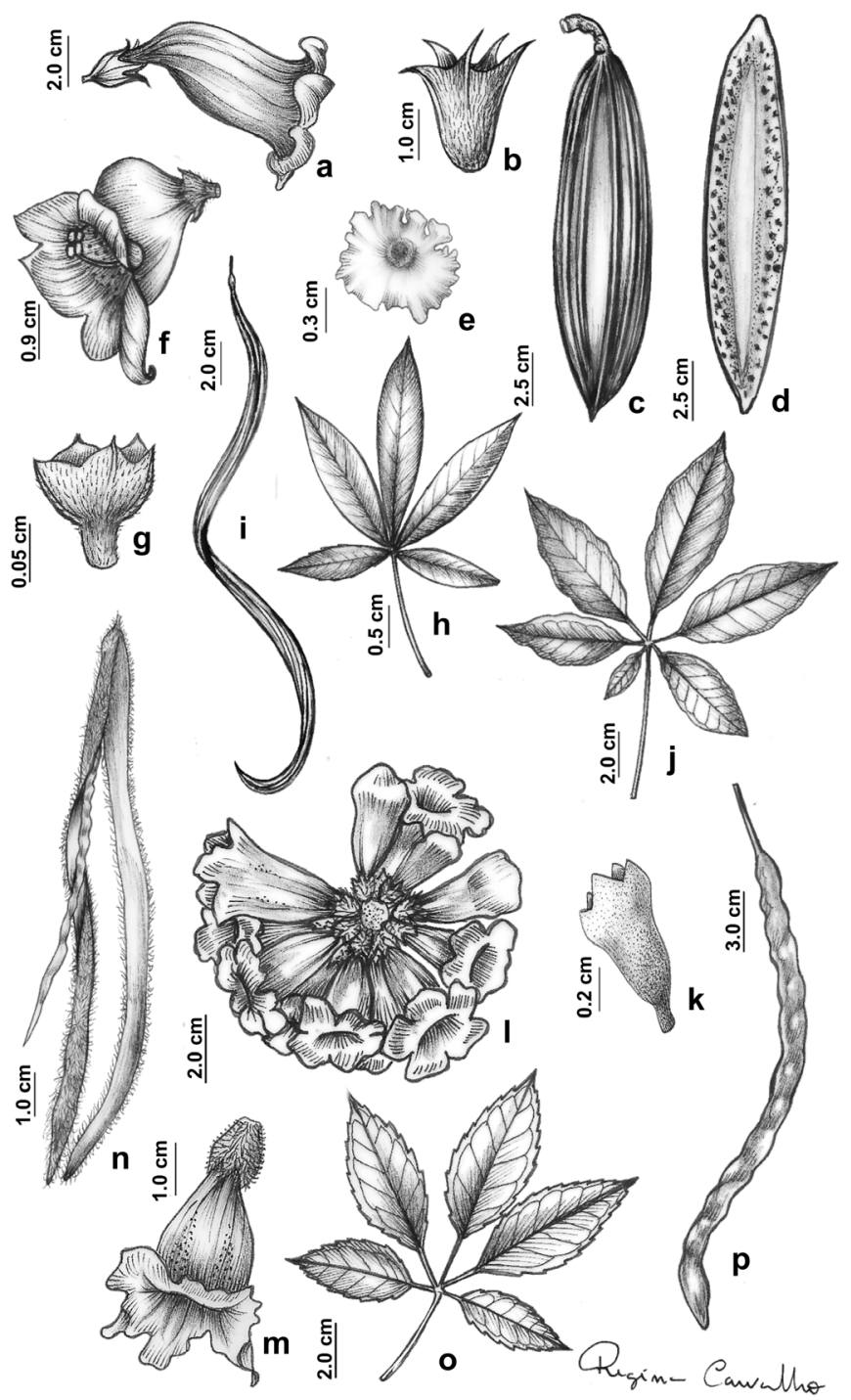

Figure 3. Cybistax antisyphilitica (Mart.) Mart.: a. Flower. b. Calyx. c. Fruit. d. Fruit replum. e. Seed. Godmania dardanoi (J.C. Gomes) A.H. Gentry: f. Flower. g. Calyx. h. Leaf. i. Fruit. Handroanthus capitatus (Bureau \& K. Schum) Mattos: j. Leaf. k. Calyx. Handroanthus chrysotrichus (Mart. ex DC.) Mattos: I. Inflorescence. m. Flower. n. Fruit. Handroanthus heptaphyllus (Vell.) Mattos: o. Leaf. p. Fruit.

Habitat and Distribution: Cybistax antisyphilitica occurs in Peru, Bolivia, Paraguay, Argentina and, disjointly, in Suriname (Gentry 1992). In Brazil it is distributed in all phytogeographical domains, occurring from Pará to Santa Catarina (Lohmann 2010). This species is a new record for the state of Pernambuco. It was found in a Caatinga area, at high altitudes (ca. $875 \mathrm{~m}$ ).

Phenology: Collected with flowers and fruits in December.

Taxonomic Notes: Cybistax antisyphilitica can be recognized by the calyx 5-dentate, with teeth long acuminate (Figure 3a-b), and oblong fruit, longitudinally ribbed (Figure $3 \mathrm{c}-\mathrm{d}$ ). This is the only species in the Bignoniaceae with light green corollas, which led to the popular name "ipê verde."

Examined Material: BRAZIL. PERNAMBUCO: Serrita, Serra de Brejinho, 14.12.2012, fl. e fr., R.A. Silva 2493 (HVASF 18878). 
Additional Examined Material: BRAZIL. CEARÁ: Santana do Cariri, 04.12.1974, fl., Academia Brasileira de Ciências 1154 (IPA 21491).

Godmania Hemsley, Diagn. pl. nov. mexic. 35, 1879.

The genus includes two species, G. aesculifolia and G. dardanoi, distributed from Mexico to Brazil and Bolivia. In Pernambuco the genus is represented by Godmania dardanoi.

2. Godmania dardanoi (J.C. Gomes) A.H. Gentry, Ann. Missouri Bot. Gard., 63: 74, 1936. Figure $3 f-i$.

Tree, 3-10 m alt.; branchlets cylindrical, striated, with lenticels, pubescent, with simple trichomes. Leaves palmate, $4-6$ foliolate; petiole 1.5-6.7 cm long, pubescent, with simple trichomes; petiolule absent; leaflets chartaceous, $1.7-4.9 \times 0.7-1.5 \mathrm{~cm}$, elliptic, base cuneate, apex acute, margin entire to irregularly serrate, discolorous, pubescent, with simple trichomes in both sides, abaxial surface grayish; venation camptodromous. Inflorescence in thyrse, terminal; bracts $0.1-0.3 \mathrm{~cm}$ long, lanceolate; bracteoles $0.1-0.2$ $\mathrm{cm}$ long, lanceolate. Calyx cupular, $0.1-0.3 \times 0.1-0.2 \mathrm{~cm}$, 5-dentate, teeth attenuated, green, pubescent, with simple trichomes, caducous. Corolla campanulate to urceolate, $2.0-3.9 \times 0.9-2.1 \mathrm{~cm}$, externally cream and internally with purple spots, lobes cuneate and facing out, pubescent externally, with simple and glandular trichomes; stamens included, anthers ca. $0.2 \mathrm{~cm}$ long, pubescent, dorsal filaments $1.7-1.8 \mathrm{~cm}$ long, ventral filaments $1.4-1.5 \mathrm{~cm}$ long, staminode shorter than fertile stamens, ca. $0.2 \mathrm{~cm}$ long; ovary sessile, linear-oblong, $0.3 \times 0.1 \mathrm{~cm}$, lepidote, style ca. $1.7 \mathrm{~cm}$ long, stigma ca. $0.2 \mathrm{~cm}$ long, lanceolate. Capsule $22.3-33.4 \times 0.4-0.6 \mathrm{~cm}$, linear-twisted, flattened, smooth, with longitudinal ridges along the entire length, pubescent surface, with simple trichomes, margin entire. Seeds winged, $4.5 \times 0.5 \mathrm{~cm}$, elliptic, wings hyaline, lengthy, membranaceous.

Habitat and Distribution: Godmania dardanoi is endemic to the Brazilian Northeast, occurring in the states of Bahia, Ceará, Pernambuco, Piauí, and Paraíba, in Caatinga and Cerrado environments (Lohmann 2010; Brito et al. 2018). In Pernambuco this species was found in areas of Caatinga, near rivers and roadside.

Phenology: Collected with flowers from June to January and with fruits in February.

Taxonomic Notes: Godmania dardanoi is recognized by the sessile leaflets, trait that differentiates this species from the other species in the genus (Figure 3h), corolla campanulate to urceolate (Figure 3f), internally with purple spots and fruit twisted and longitudinally ridged (Figure 3i). This species is popularly known in the study area as "chifre-de-carneiro" or "tapioca."

Selected Material: BRAZIL. PERNAMBUCO: Araripina, 19.11.1992, fl., A.M. Miranda et al. 671 (HUFRN 2157); Ipubi, 08.02.1983, fl. and fr. G. Fotius 3345 (HUEFS 173093).

\section{Handroanthus Mattos, Loefgrenia, 50: 2, 1970.}

Small and large trees. Leaves palmate, 3-6 foliolate. Inflorescence terminal, a panicle or cyme. Calyx cupular, coriaceous, pubescent, tomentose, lepidote or villose. Corolla infundibuliform, yellow, pink, lilac or purple; stamens included, anthers glabrous, staminode shorter than fertile stamens. Capsule linear-cylindrical, flattened. Seeds winged, wings hyaline, membranaceous.

Handroanthus is represented in the state of Pernambuco by 30 species distributed from Central and South America and Antilles (Gentry 1992). In Brazil 27 species (15 endemic) are found (Lohmann 2010).
In the study area eight species were found, H. capitatus, H. chrysotrichus, $H$. heptaphyllus, $H$. impetiginosus, $H$. ochraceus, H. serratifolius, $H$. spongiosus, and H. umbellatus.

\section{Identification key for the Handroanthus species occurring in the state of Pernambuco}

1. Corolla pink or lilac

2. Leaflets with margins entire, sometimes irregularly serrate, pubescent in adaxial surface and glabrescent to tomentose in abaxial surface, with simple trichomes; calyx pubescent with stellate and simple trichomes; capsule without irregular constrictions

6. H. impetiginosus

2 '. Leaflets with margins serrate, glabrous; calyx sparsely lepidote; capsule with irregular constrictions 5. H. heptaphyllus

1'. Corolla yellow

3. Inflorescence in cyme or fascicle

4. Leaves 3-foliolate, strongly discolorous; calyx deeply 5-dentate with a thin membrane between teeth .................. 9. H. spongiosus

4'. Leaves 5-foliolate, concolorous; calyx irregularly 3-5 dentate with longitudinal ribs along this 10. H. umbellatus

3'. Inflorescence in panicle

5. Leaflets glabrescent or lepidote

6. Branchlets tetragonal, with stellate trichomes, without lenticels; ovary linear-oblong, densely lepidote

3. H. capitatus

6'. Branchlets cylindrical, with simple trichomes, with lenticels; ovary ovate, pubescent with glandular trichomes

8. H. serratifolius

5'. Leaflets pubescent or tomentose

7. Leaflets with abaxial surface rusty; sessile flowers; capsule with lanuginous indument ..................... 4. H. chrysotrichus

7'. Leaflets with abaxial surface whitish; pedicellate flowers; capsule with floccose indument ....................... 7. H. ochraceus

\section{Handroanthus capitatus (Bureau \& K. Schum) Mattos, Loefgrenia, 50: 4, 1970. Figure $3 j-k$.}

Tree; branchlets tetragonal, striated, without lenticels, pubescent, with stellate trichomes. Leaves 5-6 foliolate; petiole 5.5-6.2 cm long, pubescent, with stellate trichomes; petiolule $2.0-2.6 \mathrm{~cm}$ long, pubescent, with stellate trichomes; leaflets chartaceous, 7.2-14.1 $\times 4.2-5.8 \mathrm{~cm}$, elliptic, base rounded, apex acuminate, margin entire, concolorous, adaxial surface glabrescent, abaxial surface pubescent only along the main vein and in the axils of the secondary veins, with stellate trichomes; venation brochidodromous. Inflorescence in panicle. Calyx $0.7-1.2$ $\times 0.5-0.8 \mathrm{~cm}$, irregulary dentate, pubescent, with stellate trichomes. Corolla 4.9-7.2 × 0.9-1.5 cm, yellow, glabrous externally; anthers ca. $0.2 \mathrm{~cm}$ long, dorsal filaments ca. $1.7 \mathrm{~cm}$ long, ventral filaments ca. 1.4 cm long, staminode ca. $0.2 \mathrm{~cm}$ long; ovary linear-oblong, $0.2 \times 0.1$ $\mathrm{cm}$, densely lepidote, style ca. $2.0 \mathrm{~cm}$ long, stigma ca. $0.2 \mathrm{~cm}$ long. Fruits and seeds not seen.

Habitat and Distribution: Handroanthus capitatus is distributed through Guyana, Suriname, Peru, Venezuela, and Brazil. This species is restricted to the Amazonian domain, where it occurs in north and northeastern Brazil (Maranhão only) (Gentry 1992, Lohmann 2010). 
Despite that, a specimen from the Atlantic Forest of Brazil (D. AndradeLima 52-1000) was identified by Gentry (1979) as H. capitatus due to the densely lepidote ovary. Even though we were able to verify the identity of this specimen, it is possible that this specimen may have been cultivated in this region.

Phenology: Collected with flowers in March.

Taxonomic Notes: Handroanthus capitatus can be recognized by the branchlets and calyx with stellate trichomes (Figure 3k), by the leaflets entire, pubescent along the main vein and axils of the secondary veins (abaxial surface), and by the densely lepidote ovary.

Examined Material: BRAZIL. PERNAMBUCO: São Lourenço da Mata, Usina Tiuma, 13.03.1952, fl., D. Andrade-Lima 52-1000 (IPA 2482).

\section{Handroanthus chrysotrichus (Mart. ex DC.) Mattos, Loefgrenia, 50: 4, 1970. Figure $3 l-n$.}

Tree, 8-10 m; branchlets cylindrical, striated, with lenticels, pubescent, with stellate trichomes. Leaves 3-5 foliolate; petiole 1.3-2.9 cm long, tomentose, with stellate trichomes; petiolules 0.5-1.8 cm long, tomentose, with stellate trichomes; leaflets chartaceous, 3.0-7.2 $\times 1.7-3.3 \mathrm{~cm}$, obovate to elliptic, base cuneate, apex cuneate to cuspidate, margin entire, discolorous, adaxial surface tomentose, with stellate trichomes, abaxial surface rusty, tomentose, with simple and stellate trichomes; venation brochidodromous. Inflorescence in panicle, congest, sessile flowers. Calyx 0.5-1.9 $\times$ $0.3-0.8 \mathrm{~cm}, 5$-dentate, teeth acute, rust, tomentose, with rust stellate and dendritic trichomes, persistent. Corolla $2.8-6.5 \times 0.5-2.1 \mathrm{~cm}$, yellow, externally pubescent, with simple trichomes; anthers ca. 0.3 cm long, dorsal filaments $2.1-2.3 \mathrm{~cm}$ long, ventral filaments $1.8-1.9$ cm long staminode ca. $0.2 \mathrm{~cm}$ long; ovary sessile, linear-oblong, 0.3 $\times 0.2 \mathrm{~cm}$, pubescent, with glandular trichomes, style ca. $2.0 \mathrm{~cm}$ long, stigma ca. $0.2 \mathrm{~cm}$ long, lanceolate. Capsule $10.2-15.2 \times 0.9-1.7 \mathrm{~cm}$, rusty, lanuginous surface, with simple and stellate trichomes, margin entire. Seeds not seen.

Habitat and Distribution: Handroanthus chrysotrichus is found in Argentina and in Cerrado and Atlantic Forest environments along the Brazilian coast (Lohmann 2010). In Pernambuco it occurs in areas of Caatinga and Atlantic Forest, in rocky outcrops and "brejos de altitude," with altitudes varying from 400 to $1080 \mathrm{~m}$.

Phenology: Collected with flowers in September, October and January and with fruits in January.

Taxonomic Notes: Handroanthus chrysotrichus and H. ochraceus are morphologically similar due to the shared leaflet shape (obovate to elliptic), texture (chartaceous), trichomes type (stellate), inflorescence type (a congest panicle; Figure 31 and 4c) and shape (linear-cylindrical), and capsule color (rusty) (Figure $3 \mathrm{n}$ and $4 \mathrm{e}$ ). These species can be differentiated by the leaflet with rusty abaxial surface (vs. whitish abaxial surface in H. ochraceus), sessile flowers (Figure 31) (vs. pedicellate flowers; Figure 4c), and capsule with indument lanuginous (vs. with floccose indument).

Selected Material: BRAZIL. PERNAMBUCO: Maraial, Engenho Curtume, 25.11.2007, fr., M. Sobral-Leite 561 (UFP 50292); Caruaru, Brejo dos Cavalos, 09.01.1999, fl., E. Locatelli \& P. Medeiros s.n. (UFP 39390)

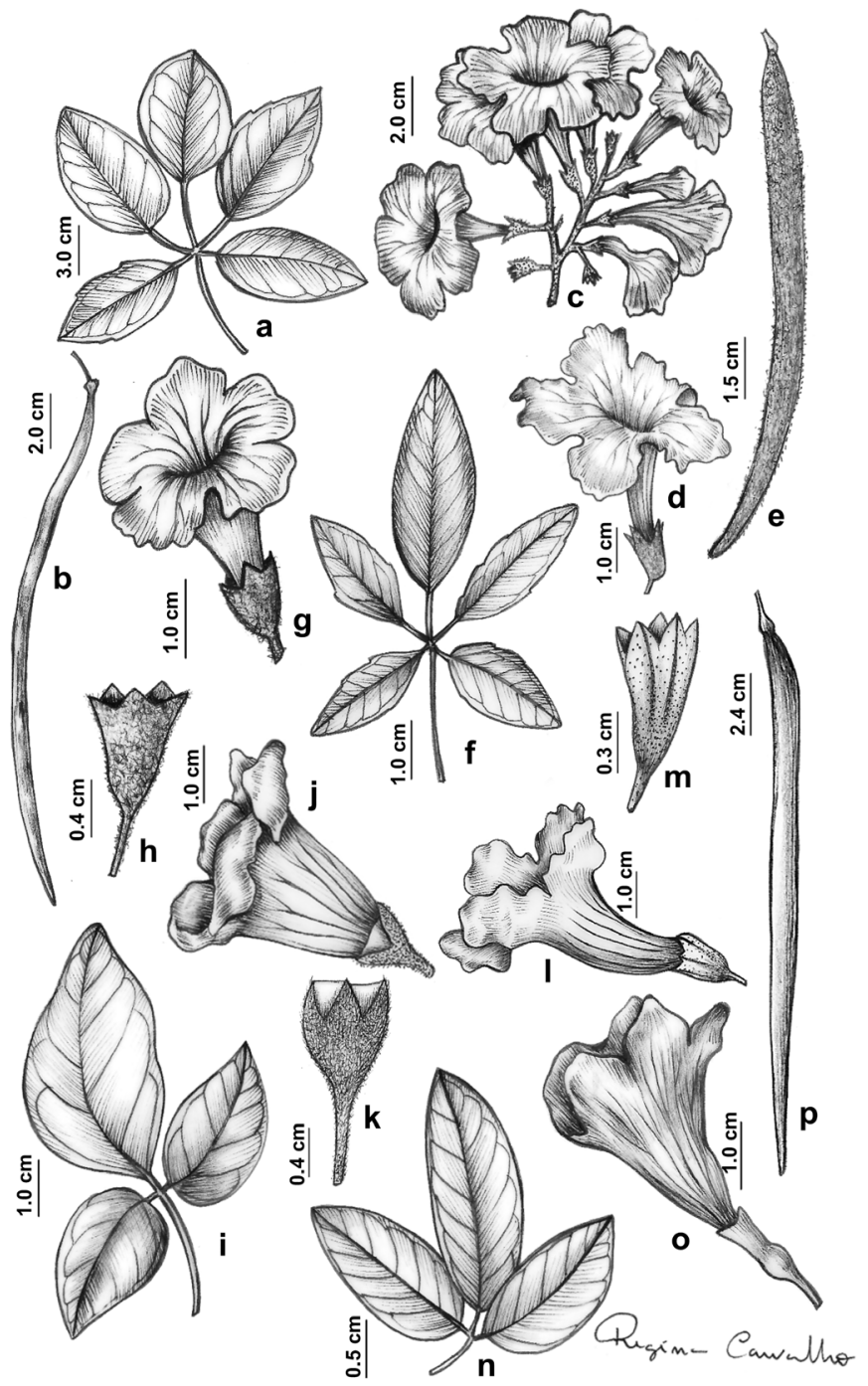

Figure 4. Handroanthus impetiginosus (Mart. ex DC.) Mattos: a. Leaf. b. Fruit. Handroanthus ochraceus (Cham.) Mattos: c. Inflorescence. d. Flower. e. Fruit. Handroanthus serratifolius (Vahl.) S. Grose: f. Leaf. g. Flower. h. Calyx. Handroanthus spongiosus (Rizzini) S. Grose: i. Leaf. j. Flower. k. Calyx. Handroanthus umbellatus (Sond.) Mattos: I. Flower. m. Calyx. Sparattosperma catingae A.H. Gentry: n. Leaf. o. Flower. p. Fruit.

\section{Handroanthus heptaphyllus (Vell.) Mattos, Loefgrenia, 50:2, 1970. Figure $3 o-p$.}

Tree; branchlets cylindrical, striated, with lenticels, glabrous. Leaves 5-6 foliolate; petiole 2.8-9.8 cm long, glabrous; petiolule 0.8-2.8 cm long, glabrous; leaflets chartaceous, 3.0-10.9 × 1.3-5.2 $\mathrm{cm}$, obovate to elliptic, base obtuse, apex acute to attenuate, margin serrate, concolorous, glabrous in both sides; venation brochidodromous. Inflorescence in panicle, pedicellate flowers. Calyx $0.3-0.9 \times$ $0.2-0.5 \mathrm{~cm}, 5-$ dentate, teeth obtuse, lilac, sparsely lepidote, caducous. Corolla $2.2-5.8 \times 1.2-2.7 \mathrm{~cm}$, lilac with yellow nectar guides, externally pubescent, with simple trichomes; anthers ca. $0.3 \mathrm{~cm}$ long, dorsal filaments $2.2-2.3 \mathrm{~cm}$ long, ventral filaments $1.5-1.6 \mathrm{~cm}$ 
long, staminode ca. $0.3 \mathrm{~cm}$ long; ovary sessile, oblong, $0.3 \times 0.1 \mathrm{~cm}$, pubescent, with glandular trichomes, style ca. $2.7 \mathrm{~cm}$ long, stigma ca. $0.3 \mathrm{~cm}$ long, lanceolate. Capsule $24.5 \times 1.3 \mathrm{~cm}$, glabrous surface, margin with irregular constrictions, with lenticels. Seeds $0.5-1.9 \times$ $0.2-0.3 \mathrm{~cm}$, narrow-elliptic.

Habitat and Distribution: Handroanthus heptaphyllus occurs in wet forests of Paraguay, western Bolivia and northeastern Argentina (Gentry 1992). In Brazil it is found in Cerrado and Atlantic Forest environments and is distributed in all states of the South, Southeastern and Midwestern regions, as well as in the Northeastern states of Bahia, Pernambuco and Ceará (Lohmann 2010). In the study area this species was found in areas of Caatinga with altitude around $400 \mathrm{~m}$.

Phenology: Collected with flowers in September and October and with fruits in January.

Taxonomic Notes: Most specimens of $H$. heptaphyllus deposited in herbaria are identified as $H$. impetiginosus. Both species have glabrous branchlets, terminal panicle inflorescence, cupular calyx, 5dentate and pink to lilac flowers with yellow to orange nectar guides. However, these species can be differentiated by leaflets glabrous (vs. pubescent with simple trichomes in $H$. impetiginosus), with serrate margin (Figure 3o) (vs. entire margins; Figure 4a), calyx sparsely lepidote (vs. pubescent with stellate trichomes), and fruit with irregular constrictions (Figure 3p) (vs. fruit with linear margin; Figure 4b).

Selected Material: BRAZIL. PERNAMBUCO: Tacaratu, 13.09.1990, fl., R. Pereira \& A. Bocage 101 (IPA 53701); Tacaratu, 15.01.2009, fr., J.G. Carvalho-Sobrinho et al. 1802 (HVASF 2845).

6. Handroanthus impetiginosus (Mart. ex DC.) Mattos, Loefgrenia, 50: 2, 1970. Figure $4 a-b$.

Tree; branchlets cylindrical, striated, with lenticels, glabrous. Leaves 3-5 foliolate; petiole 2.2-9.2 cm long, glabrous; petiolule 0.8-3.9 cm long, glabrous; leaflets chartaceous, 1.2-15.7 × 1.3-6.9 $\mathrm{cm}$, elliptics, narrow-elliptic or obovate, base rounded, apex acute to acuminate, margin entire, sometimes irregulary serrate, concolorous, rarely discolorous, adaxial surface pubescent, with simple trichomes, abaxial surface glabrescent to tomentose, with simple trichomes; venation brochidodromous. Inflorescence in panicle, congest, glabrous to densely tomentose; bracts and bracteoles $0.1-0.2 \mathrm{~cm}$ long, narrow-elliptic. Calyx $0.2-1.0 \times 0.2-0.7 \mathrm{~cm}, 5$-dentate to truncate, teeth cuneate, lilac, densely pubescent, glandular, with stellate and simple trichomes, persistent. Corolla 2.2-6.7 $\times 0.9-3.3$ $\mathrm{cm}$, pink to lilac with yellow, pink or orange nectar guides, externally pubescent, with simple trichomes; anthers ca. $0.2-0.3 \mathrm{~cm}$ long, dorsal filaments $1.8-2.0 \mathrm{~cm}$ long, ventral filaments $1.5-1.6 \mathrm{~cm}$ long, staminode ca. $0.2 \mathrm{~cm}$ long; ovary sessile, oblong, $0.3 \times 0.2 \mathrm{~cm}$, lepidote, style ca. $2.5 \mathrm{~cm}$ long, stigma ca. $0.2 \mathrm{~cm}$ long, lanceolate. Capsule 10.9-32.3 × 1.0-1.3 cm, glabrous surface, green to dark brown, margin without irregular constrictions. Seeds $0.5-1.7 \times$ $0.2-0.4 \mathrm{~cm}$, narrow-elliptic.

Habitat and Distribution: Handroanthus impetiginosus is distributed from Northeastern Mexico to Argentina (Gentry 1992), and is widely distributed throughout the Brazilian territory (except for the southern region), where it occurs in Amazonia, Caatinga, Cerrado, Atlantic Forest, and Pantanal (Lohmann 2010). In Pernambuco it was found in areas of Caatinga, Atlantic Forest, "brejos de altitude," anthropic areas, and rocky outcrops, between 300 to $1200 \mathrm{~m}$ alt.
Phenology: Collected with flowers from April to December and fruits from July to March.

Taxonomic Notes: Handroanthus impetiginosus can be recognized by leaflets with entire margins (Figure 4a), pubescent with simple trichomes, pink to lilac flowers with yellow to orange nectar guides, by the calyx pubescent with stellate trichomes, and by the fruit with linear margins (Figure $4 b$ ). The similarity with $H$ heptaphyllus is discussed under that species comments.

Selected Material: BRAZIL. PERNAMBUCO: São Joaquim do Monte, 8²3'43"S 3551'02”'W, 27.I.2014, fr., M. Oliveira 5736 (IPA); Buíque, Parque Nacional do Catimbau, 14.IX. 2011, fl., A.C.G. Costa et al. 45 (IPA).

\section{Handroanthus ochraceus (Cham.) Mattos, Loefgrenia, 50: 2, 1970. Figure $4 c-e$.}

Tree; branchlets cylindrical, striated, with lenticels, pubescent, with stellate trichomes. Leaves 5-foliolate; petiole 3.1-5.6 cm long, tomentose, stellate trichomes; petiolules $1.2-3.3 \mathrm{~cm}$ long, stellate trichomes; leaflets chartaceous, $4.2-10.1 \times 3.1-7.3 \mathrm{~cm}$, obovate to elliptic, base cordate, apex retuse to rounded, margin entire, rarely serrated, sometimes sinuate, discolorous, adaxial surface pubescent only along of main veins and in axils of secondary veins, with stellate trichomes, abaxial surface pubescent, with whitish stellate trichomes; venation brochidodromous. Inflorescence in panicle, congest, pedicellate flowers. Calyx $0.5-1.5 \times 0.5-1.0 \mathrm{~cm}, 5-$ dentate, teeth acute, rust, villose, with simple and stellate trichomes, persistent. Corolla $3.0-5.9 \times 0.9-2.8 \mathrm{~cm}$, yellow with wine ribs, externally glabrous and internally pubescent, with simple and stellate trichomes; anthers $0.2-0.3 \mathrm{~cm}$, dorsal filaments ca. $2.1 \mathrm{~cm}$ long, ventral filaments ca. $1.8 \mathrm{~cm}$ long, staminode ca. $0.2 \mathrm{~cm}$ long; ovary sessile, oblong, 0.2 $\times 0.1 \mathrm{~cm}$, pubescent, style ca. $2.0 \mathrm{~cm}$ long, stigma ca. $0.2 \mathrm{~cm}$ long, lanceolate. Capsule 9.2-13.2 $\times 0.8-1.5 \mathrm{~cm}$, floccose surface, with stellate trichomes, rust, margin entire, without lenticels. Seeds $1.6 \times$ $0.6 \mathrm{~cm}$, elliptic.

Habitat and Distribution: Handroanthus ochraceus is found in dry forests from Guatemala to Argentina, from sea level up to $1600 \mathrm{~m}$ (Gentry 1992). It is widely distributed throughout Brazil, where it occurs in Amazonia, Caatinga, Cerrado, and Atlantic Forest domains (Lohmann 2010). In the study area it was found in Atlantic Forest and Caatinga, "brejos de altitude," and rocky outcrops.

Phenology: Collected with flowers in September to February, and fruits from September to November.

Taxonomic Notes: Handroanthus ochraceus can be recognized by obovate to elliptic leaflets with a whitish abaxial surface, by the pedicellate flowers (Figure 4c), and the capsule with floccose indumentum (Figure 4e). The similarity and differences with $H$. chrysotrichus are discussed under that species comments.

Selected Material: BRAZIL. PERNAMBUCO: Brejo dos cavalos, 01.III.1996, fr., D.S. Pimentel 55 (PEUFR 25148); Pesqueira, 28.IX.1995, fl., M. Correia 371 (IPA 58254)

8. Handroanthus serratifolius (Vahl.) S. Grose, Syst. Bot., 32: 666, 2007. Figure $4 f-h$.

Tree; branchlets cylindrical, striated, with lenticels, pubescent, with simple trichomes. Leaves 3-5 foliolate; petiole 1.5-3.9 cm long, pubescent, with simple trichomes; petiolule $0.9-1.3 \mathrm{~cm}$ long, pubescent, 
with simple trichomes; leaflets chartaceous, $3.1-7.3 \times 1.9-4.1 \mathrm{~cm}$, elliptic to obovate-elliptic, base cuneate to rounded, apex acuminate, margin entire, serrated or irregulary serrated, concolorous, lepidote on both sides; venation brochidodromous. Inflorescence in panicle; bracts and bracteoles absent. Calyx $0.7-1.4 \times 0.5-0.9 \mathrm{~cm}, 3-5$ dentate to irregulary dentate, teeth cuneate, green, pubescent, with simple and stellate trichomes, caducous. Corolla 4.8-7.9 $\times 0.8-2.2 \mathrm{~cm}$, yellow, externally glabrous; anthers ca. $0.3 \mathrm{~cm}$ long, dorsal filaments $2.2-2.4$ cm long, ventral filaments $1.7-1.8 \mathrm{~cm}$ long, staminode ca. $0.3 \mathrm{~cm}$ long; ovary sessile, ovate, $0.3 \times 0.2 \mathrm{~cm}$ long, pubescent, glandular trichomes, style ca. $3.1 \mathrm{~cm}$ long, stigma ca. $0.3 \mathrm{~cm}$ long. Capsule $18.3-39.8 \times$ $0.7-1.5 \mathrm{~cm}$, glabrous surface, margin entire, without lenticels. Seeds not seen.

Habitat and Distribution: Handroanthus serratifolius occurs from Colombia to Bolivia in wet and dry forests (Gentry 1992). In Brazil this species is widely distributed throughout most of the territory (except the states of Rio Grande do Sul and Santa Catarina in the southern region), where it occurs in areas of Caatinga, Cerrado, Atlantic Forest, Pantanal, and Amazon forests (Lohmann 2010). In Pernambuco it occurs in the Atlantic Forest and Caatinga.

Phenology: Collected with flowers from November to January and with fruits in August.

Taxonomic Notes: Handroanthus serratifolius can be identified by the leaflets with entire, serrated or irregulary serrate margins (Figure 4f), and the calyx with cuneate teeth (Figure 4h), with simple and stellate trichomes.

Selected Material: BRAZIL. PERNAMBUCO: Exu, Serra da Gameleira, 06.VIII.1986, fr., V.C. Lima 337 (IPA 49180); Bonito, 29.I.1970, fl., Andrade-Lima 70-5683 (IPA 20913).

\section{Handroanthus spongiosus (Rizzini) S. Grose, Syst. Bot.,} 32: 666, 2007. Figure $4 i-k$.

Tree; branchlets cylindrical, striated, without lenticels, pubescent, with stellate trichomes. Leaves 3 -foliolate; petiole 1.1$4.2 \mathrm{~cm}$ long, tomentose, with stellate trichomes; petiolules $0.5-1.0$ $\mathrm{cm}$ long, tomentose, with stellate trichomes; leaflets membranaceous, $4.5-8.7 \times 1.9-3.3 \mathrm{~cm}$, elliptic to obovate-elliptic, base obtuse to rounded, apex attenuate, margin entire, strongly discolorous, adaxial surface tomentose, with stellate trichomes, abaxial surface densely tomentose, with whitish stellate trichomes, sometimes rusty; venation brochidodromous. Inflorescence a dicasial cyme, densely tomentose, with stellate rusty trichomes; bracts and bracteoles absent. Calyx $0.3-1.7 \times 0.3-0.8 \mathrm{~cm}$, deeply 5-dentate with a thin membrane between the teeth, rusty, densely tomentose, with rusty stellate trichomes, persistent. Corolla $1.8-4.9 \times 1.2-1.5 \mathrm{~cm}$, yellow with red nectar guides, externally glabrous; anthers ca. $0.2 \mathrm{~cm}$ long, dorsal filaments $1.9-2.1 \mathrm{~cm}$ long, ventral filaments $1.7-1.8 \mathrm{~cm}$ long, staminode ca. $0.2 \mathrm{~cm}$ long; ovary sessile, linear, ca. $0.2 \mathrm{~cm}$ long, lepidote, style ca. $3.5 \mathrm{~cm}$ long, stigma ca. $0.2 \mathrm{~cm}$ long. Capsule $13.1-22.5 \times 0.6-0.8 \mathrm{~cm}$, base cuneate, apex attenuate, glabrous surface, margin with irregular constrictions, without lenticels. Seeds $2.1 \times 0.5 \mathrm{~cm}$, oblong-elliptic.

Habitat and Distribution: This species is endemic to Northeastern Brazil, where it occurs in the states of Alagoas, Bahia, Paraiba, Pernambuco, Piauí and Sergipe (Lohmann 2010). In Pernambuco it occurs in Caatinga, between 300 to $400 \mathrm{~m}$ of altitude.
Phenology: Collected with flowers in May, August and October to January, and with fruits from November to February.

Taxonomic Notes: Handroanthus spongiosus is characterized by 3 foliolate leaves (Figure 4i), densely tomentose leaflets, inflorescence and calyx, with stellate rusty trichomes, and calyx deeply 5-dentate with a thin membrane between the teeth (Figure $4 \mathrm{j}-\mathrm{k}$ ). In the field, it can be identified by the yellow flowers with red nectar guides, and by the flaky bark. This species is known in the region by the common names "sete cascas" and/or "cascudo."

Selected Material: BRAZIL. PERNAMBUCO: Lagoa Grande, Fazenda Cabana, 08³0'25,84’'S 40¹5'33,64”'W, 10.XII.2012, fr., A.C.P Oliveira et al. 2044 (HVASF 18918); Petrolina, 0848'07'S 4048'04'W, 534 m, 21.XI.2011, fl., T.S. Oliveira et al. 73 (HVASF 13431).

10. Handroanthus umbellatus (Sond.) Mattos, Loefgrenia, 50: 2, 1970. Figure $4 l-m$.

Tree; branchlets cylindrical, striated, with lenticels, sparsely pubescent, with stellate trichomes. Leaves 5-foliolate; petiole $3.0-4.2 \mathrm{~cm}$ long, densely pubescent, with stellate trichomes; petiolules $1.5-2.3 \mathrm{~cm}$ long, densely pubescent, with simple trichomes; leaflets membranaceous, 5.5-8.9 $\times$ $1.7-4.6 \mathrm{~cm}$, elliptics, base obtuse, apex acuminate, margin entire, concolorous, pubescent on both sides, with stellate trichomes; venation brochidodromous. Inflorescence a fascicle; bracts and bracteoles absent. Calyx 0.6-2.0 $\times$ $0.4-0.9 \mathrm{~cm}$, irregulary $3-5$ dentate, teeth cuneate, with longitudinal ribs along to calyx, green to yellow, densely tomentose on base and on ribs, sparsely pubescent on apex, with stellate trichomes. Corolla 4.2-7.7 $\times$ $1.5-2.1 \mathrm{~cm}$, yellow, glabrous externally; anthers ca. $0.3 \mathrm{~cm}$ long, dorsal filaments $2.0-2.1 \mathrm{~cm}$ long, ventral filaments $1.4-1.5 \mathrm{~cm}$ long, staminode ca. $0.3 \mathrm{~cm}$ long; ovary sessile linear-cylindrical, $0.3 \times 0.1 \mathrm{~cm}$, lepidote, style ca. $2.2 \mathrm{~cm}$ long, stigma ca. $0.3 \mathrm{~cm}$ long, lanceolate. Fruit and seeds not seen. Habitat and Distribution: Handroanthus umbellatus is endemic to Brazil, where it occurs in Atlantic Forest vegetation along the Brazilian coast, from Rio Grande do Sul to Bahia (Lohmann 2010). It represents a new record for the state of Pernambuco, where it occurs in the Atlantic Forest, at forest edges, with altitudes ranging between 400-600 m.

Phenology: Collected with flowers in January and February.

Taxonomic Notes: Handroanthus umbellatus is recognized by the calyx densely tomentose at the base and sparsely pubescent at apex, longitudinally ribbed (Figure 4l-m).

Examined Material: BRAZIL. PERNAMBUCO: Bezerros, Parque Ecológico Serra Negra, 08.02.1996, fl., E. Inácio et al. 139 (MO); São Vicente Férrer, Mata do Estado, 29.01.1999, fl., E.M.N. Ferraz et al. 583 (MO).

\section{Jacaranda Jussieu, Gen. Pl. 138, 1789.}

Trees or shrubs. Leaves bipinnate or pinnate. Inflorescence a panicle, terminal or axillar. Calyx campanulate, pubescent, glabrescent, villose or lepidote; corolla infundibuliform with the narrow base, purple, blue, wine or lilac; stamens included, anthers mono-thecae or di-thecae, staminode larger than fertile stamens, pubescent from half to apex, glandular trichomes. Capsule wide-elliptic, elliptic or ovate, flattened or inflated. Seeds winged, wings hyaline, membranaceous.

Jacaranda includes 49 species distributed from Guatemala to Argentina (Gentry 1992). In Brazil, 36 species (32 endemic) are found (Lohmann 2010). Six species are found in the study area (i.e., J. brasiliana, J. cuspidifolia, J. jasminoides, J. microcalyx, $J$. puberula, and J. rugosa). 


\section{Identification key for Jacaranda species occurring in the state of Pernambuco}

1. Anthers mono-thecae

2. Pinnules concolorous; calyx lobes ovate with acute apex, not reflexed, divided almost to the base; capsule inflated and undulate at dehiscence 11. J. brasiliana

2'. Pinnules discolorous; calyx lobes lanceolate with acuminate apex, reflexed, divided to the base; capsule flattened and smooth at dehiscence 12. J. cuspidifolia

1'. Anthers bi-thecae

3. Leaves pinnate completely or pinnate on base and bipinnate at apex; leaflets coriaceous; inflorescence axillary

4. Leaflets with smooth surface; bracts and bracteoles narrowelliptic; calyx sparsely pubescent ................. 13. J. jasminoides 4'. Leaflets with rugose surface; bracts and bracteoles absent; calyx villose .................................... 16. J. rugosa

3'. Leaves bipinnate; leaflets chartaceous; inflorescence terminal

5. Branchlets tetragonal; leaflets concolorous and lepidote on both sides; bracts and bracteoles absent . . . 14. J. microcalyx 5'. Branchlets cylindrical; leaflets discolorous and glabrous on adaxial surface and densely pubescent on abaxial surface; bracts and bracteoles present

15. J. puberula

11. Jacaranda brasiliana (Lam.) Pers., Syn. Pl. 2: 174, 1807. Figure 5 a-e.

Tree, $10 \mathrm{~m}$; branchlets cylindrical, winged, striated, with lenticels, sparsely pubescent, with simple trichomes. Leaves bipinnate; petiole $4.1-4.8 \mathrm{~cm}$ long, pubescent, with simple trichomes; pinnules sessile, chartaceous, $0.7-1.2 \times 0.3-0.6 \mathrm{~cm}$, elliptic to oblong-elliptic, base cuneate, apex obtuse to acute, margin entire, concolorous, adaxial surface glabrous, abaxial surface pubescent only in main veins, with simple trichomes; venation brochidodromous. Inflorescence terminal; bracts and bracteoles absent. Calyx $0.3-0.5 \times 0.2-0.3 \mathrm{~cm}, 5-$ lobed, lobes divided almost to the base, lobes ovate with acute apex, not reflexed, purple, pubescent, with glandular trichomes, caducous. Corolla 3.9-5.7 $\times 1.5-1.7 \mathrm{~cm}$, purple to blue, externally densely pubescent on base and sparsely pubescent on tube and lobes, with glandular trichomes; anthers ca. $0.2 \mathrm{~cm}$ long, mono-thecae, dorsal filaments $2.2-2.5 \mathrm{~cm}$ long, ventral filaments $1.7-1.8 \mathrm{~cm}$ long, staminode $3.0-3.3 \mathrm{~cm}$ long; disc annular, $0.2 \times 0.2 \mathrm{~cm}$; ovary ovate, $0.2 \times 0.1 \mathrm{~cm}$, glabrous, style ca. $2.4 \mathrm{~cm}$ long, stigma ca. $0.3 \mathrm{~cm}$ long, elliptic. Capsule $8.6-19.2 \times 7.7-16.8 \mathrm{~cm}$, wide-elliptic, inflated, woody, undulate at dehiscence, surface glabrous, margin entire, without lenticels. Seeds $2.1 \times 1.8 \mathrm{~cm}$, wide-elliptic.

Habitat and Distribution: Jacaranda brasiliana is endemic to Brazil, where it occurs in the Amazon, Cerrado, and Caatinga domains, from Mato Grosso to Minas Gerais and from Pará to Bahia (Lohmann 2010). In Pernambuco it occurs in environments of Caatinga with altitudes ranging from $500-890 \mathrm{~m}$.

Phenology: Collected with flowers from November to February, and with fruits in February.

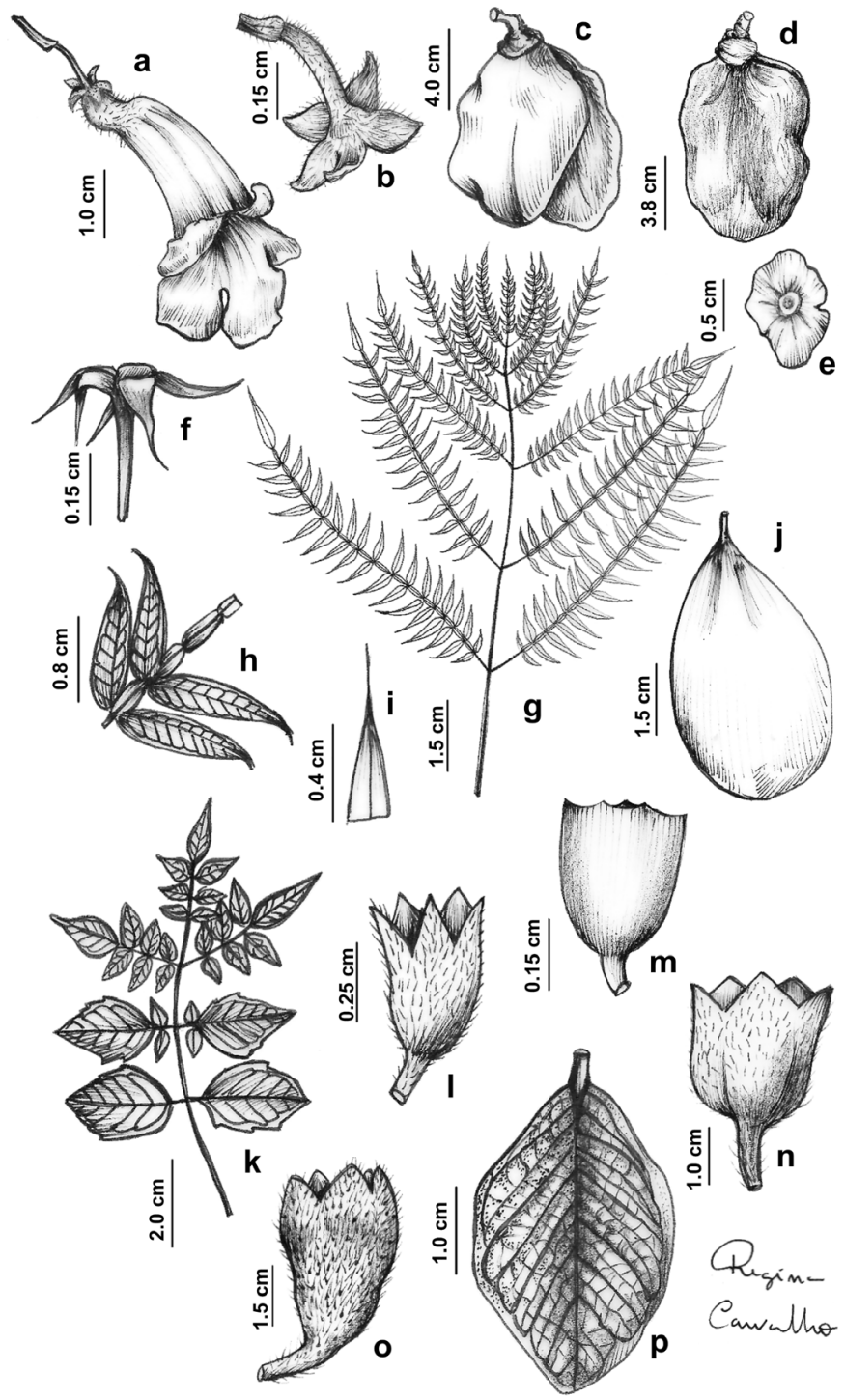

Figure 5. Jacaranda brasiliana (Lam.) Pers.: a. Flower. b. Calyx. c-d. Fruit. e. Seed. Jacaranda cuspidifolia Mart.: f. Calyx. g. Leaf. h. Detail of the leaf rachis and leaflets. i. Detail of leaflet apex. j. Fruit. Jacaranda jasminoides (Thunb.) Sandwith: k. Leaf. I. Calyx. Jacaranda microcalyx A.H. Gentry: m. Calyx. Jacaranda puberula Cham.: n. Calyx. Jacaranda rugosa A.H. Gentry: o. Calyx. p. Leaf.

Taxonomic Notes: Jacaranda brasiliana is morphologically very close to J. cuspidifolia with which it shares the cylindrical branchlets, sessile pinnules, entire pinnules margin, terminal inflorescence, and purple calyx. Despite that, J. brasiliana can be differentiated by the concolorous pinnules (vs. discolorous pinnules in J. cuspidifolia), pinnas not winged (vs. pinnas slightly winged; Figure 5h), calyx lobes ovate with acute apex, divided almost to the base (Figure 5b) (vs. lobes lanceolate with acuminate apex, divided to the base; Figure 5f), and the inflated, undulate wide-elliptic fruit (Figure 5c-d) (vs. ovate, flattened wide-elliptic fruit; Figure 5j). 
Selected Material: BRAZIL. PERNAMBUCO: Arcoverde, Serra das Varas, 890 m, 22.II.2006, fl. and fr., R. Pereira et al. 2707 (IPA 73344); São José do Belmonte, 0744'20,63”S 3841'32,69'W, 570 m, 30.VII.2013, fl., A.C.P. Oliveira et al. 2945 (HVASF 21170).

\section{Jacaranda cuspidifolia Mart., Prodr., 9: 228, 1845. Figure $5 f-j$.}

Shrubs, 8-10 m; branchlets cylindrical, striated, with lenticels, glabrous. Leaves bipinnate; petiole $2.0-4.4 \mathrm{~cm}$ long, glabrous; pinna slightly winged; pinnules sessile, membranaceous, $1.5-2.5 \times 0.3-0.6$ $\mathrm{cm}$, lanceolate to oblong, base obtuse to cuneate, apex long acuminate, margin entire, discolorous, adaxial surface glabrous, abaxial surface pubescent, with simple trichomes; venation brochidodromous. Inflorescence terminal; bracts and bracteoles absent. Calyx 5-lobed, lobes divided to the base, lobes lanceolate with apex acuminate, reflexed, $0.2-0.5 \times 0.1-0.3 \mathrm{~cm}$, purple, glabrescent, with simple trichomes on lobes margin, caducous. Corolla $2.4-5.4 \times 0.6-1.5 \mathrm{~cm}$, lilac, externally pubescent, with glandular trichomes; anthers $0.2-0.3 \mathrm{~cm}$ long, monothecae, dorsal filaments $2.5-2.6 \mathrm{~cm}$ long, ventral filaments $2.0-2.1 \mathrm{~cm}$ long, staminode ca. $2.8 \mathrm{~cm}$ long; disc annular, $0.2 \times 0.2 \mathrm{~cm}$; ovary ovate, $0.2 \times 0.1 \mathrm{~cm}$, glabrous, style ca. $2.6 \mathrm{~cm}$ long, stigma ca. $0.2 \mathrm{~cm}$ long, elliptic. Capsule 4.9-6.8 $\times 3.3-5.7 \mathrm{~cm}$, ovate to wide-elliptic, flattened, smooth at dehiscence, base rounded, apex acute, surface glabrous, margin entire, with lenticels. Seeds $1.2 \times 1.0 \mathrm{~cm}$, wide-elliptics.

Habitat and Distribution: Jacaranda cuspidifolia occurs from Argentina to Bolivia (Gentry 1992). In Brazil it is distributed through Cerrado, Atlantic Forest, and Pantanal vegetation of the Midwestern and Southeastern states (Lohmann 2010). This species is a new record for the state of Pernambuco and consequently for Northeastern Brazil. It is found in high altitude forest (above $1000 \mathrm{~m}$ ).

Phenology: Collected with flowers and with fruits in November. Taxonomic Notes: Jacaranda cuspidifolia is recognized by the pinna slightly winged (Figure 5h), the sessile leaflets (Figure 5g) that are lanceolate to oblong, with long and acuminate apices (Figure 5i), and by the calyx 5-lobed, with lanceolate and acuminate lobes divided all the way until the base and reflexed (Figure 5f). The similarity and differences with $J$. brasiliana are discussed under that species comments. Selected Material: BRAZIL. PERNAMBUCO: Recife, Santuário dos Três Reinos, 0757'41,4”S 3456'20,9'W, 99 m, 24.X.2013, fl., M. Sobral-Leite et al. 1336 (UFP 79079); Triunfo, Sítio Jardim, 17.XI.1998, fl. and fr., A.M. Miranda 3080 (HUEFS 185187).

\section{Jacaranda jasminoides (Thunb.) Sandwith, Figure 5 k-l.}

Tree or shrubs, 3-8 m; branchlets cylindrical, striated, with lenticels, pubescent, with simple and glandular trichomes. Leaves pinnate on base and bipinnate on apex, with terminal leaflet bigger; petiole $3.8-5.0 \mathrm{~cm}$ long, pubescent, with simple trichomes; leaflets and pinnules sessile, coriaceous, $0.9-5.2 \times 0.5-2.1 \mathrm{~cm}$, ovate-elliptic to ovate, base cuneate to rounded, apex acute to obtuse, margin entire, discolorous, adaxial surface sparsely pubescent, with simple trichomes, abaxial surface densely pubescent, simple trichomes, smooth surface; venation brochidodromous. Inflorescence axillar; bracts and bracteoles $0.2-0.3 \mathrm{~cm}$ long, narrow-elliptics. Calyx $0.4-0.9 \times 0.3-0.5 \mathrm{~cm}, 5$ dentate, teeth attenuate, purple to vinaceous, sparsely pubescent, with glandular trichomes, persistent. Corolla 3.1-4.2 × 1.2-1.9 cm, wine, externally sparsely pubescent, with glandular trichomes; anthers ca.
$0.2 \mathrm{~cm}$ long, di-thecae, dorsal filament $2.6-2.8 \mathrm{~cm}$ long, ventral filament 1.9-2.1 cm long, staminode ca. $4.0 \mathrm{~cm}$ long; ovary ovate, $0.2 \times 0.2$ cm, glabrous, style ca. $3.5 \mathrm{~cm}$ long, stigma ca. $0.3 \mathrm{~cm}$ long, elliptic. Capsule $4.4 \times 2.5 \mathrm{~cm}$, elliptic to wide-elliptic, woody, base and apex rounded, surface glabrous, margin entire, with lenticels. Seeds $1.2 \times$ $1.5 \mathrm{~cm}$, wide-elliptic.

Habitat and Distribution: Jacaranda jasminoides is endemic to Brazil, where it occurs along the Brazilian coast, from Ceará to Rio de Janeiro, in Caatinga, Cerrado, and Atlantic Forest vegetation (Lohmann 2010). In Pernambuco it was found in areas of Caatinga, in mountains up to $1000 \mathrm{~m}$ altitude, and rocky outcrops up to $600 \mathrm{~m}$.

Phenology: Collected with flowers from November to February, and fruits from May to December.

Taxonomic Notes: Morphologically close to J. rugosa with which it shares cylindrical branchlets, discolorous, and coriaceous leaflets, axillar inflorescences, elliptic to wide-elliptic capsules, and persistent calyx in the fruit (unusual feature in the genus). These species can be differentiated by the pinnate leaves at the base and bipinnate at the apex (Figure 5k) (vs. bipinnate leaves in throughout the leaf extension in $J$. rugosa), leaflets with smooth surface (Figure 5k) (vs. surface densely rugose; Figure 5p), and calyx 5-dentate with attenuate teeth (Figure 51) (vs. teeth cuneate to rounded; Figure 5o).

Selected Material: BRAZIL. PERNAMBUCO: Araripina, 08.VIII.1986, fr., V.C. Lima 383 (IPA 49191); Tacaratu, Serra Grande, 0904'20,70”S 38 07'34,20”W, 802 m, 23.XI.2009, fl. and fr. A.P. Fontana \& G. Rodrigues 6247 (HVASF 6460).

\section{Jacaranda microcalyx A.H. Gentry, Fl. Neotrop. Monogr., 25(2): 87, 1992. Figure $5 \mathrm{~m}$.}

Tree, 8-10 m; branchlets tetragonal, striated, with lenticels, glabrous. Leaves bipinnate; petiole $3.5-7.0 \mathrm{~cm}$ long, canaliculate, lepidote; petiolule $1.2-1.5 \mathrm{~cm}$ long, canaliculate, lepidote; pinnule subsessile, decreasing as it reaches the base; chartaceous, 3.3-9.5 $\times$ 1.6-4.7 cm, elliptic to obovate-elliptic, base obtuse to cuneate, apex attenuate to cuneate, margin entire, concolorous, adaxial surface lepidote, abaxial surface densely lepidote; venation brochidodromous. Inflorescence terminal; bract and bracteoles absent. Calyx $0.3-0.5 \times$ $0.3-0.4 \mathrm{~cm}$, truncate to minutely 5-dentate, purple, sparsely lepidote. Corolla ca. $2.5-4.7 \times 0.9-1.2 \mathrm{~cm}$, lilac to wine, externally densely pubescent, with glandular and simple trichomes; anthers ca. $0.2 \mathrm{~cm}$ long, di-thecae, dorsal filaments $2.1-2.3 \mathrm{~cm}$ long, ventral filaments $1.7-1.8$ long, staminode ca. $3.0 \mathrm{~cm}$ long; ovary oval, $0.2 \times 0.1 \mathrm{~cm}$, glabrous, style ca. $2.5 \mathrm{~cm}$ long, stigma ca. $0.2 \mathrm{~cm}$ long. Capsule 6.1-7.3 $\times 4.7-5.5$ $\mathrm{cm}$, elliptic to oblong-elliptic, flattened, woody, base attenuate, apex rounded, surface lepidote, margin slightly undulate, without lenticels. Seeds not seen.

Habitat and Distribution: Endemic to the Brazilian Northeast, where it is known from two populations growing within Atlantic Forest vegetation in Bahia and Pernambuco, respectively (Gentry 1992, Lohmann 2010).

Phenology: Collected with flowers from May to June, and fruits in February.

Taxonomic Notes: Jacaranda microcalyx is morphologically close to $J$. puberula, with which is shares chartaceous, elliptic to obovate leaflets, terminal inflorescences, and purple calyces. 
These species can be differentiated by the tetragonal branchlets (vs. cylindrical in J. puberula), leaflets subsessile and lepidote on both sides (vs. sessile and glabrous on the adaxial surface and densely pubescent on the abaxial surface), calyx truncate to minutely 5-dentate (Figure 5m) (vs. 5-dentate with cuneate teeth; Figure 5n), and bracts and bracteoles absent (vs. bracts and bracteoles lanceolate).

Examined Material: BRAZIL. PERNAMBUCO: Ipojuca, Engenheiro Maranhão, 10.VI.1967, fl., Andrade-Lima 67-5032 (IPA 16223).

Additional Examined Material: BRAZIL. BAHIA: (Type Specimen) Ubaitaba-Itacaré, $14^{\circ} 20^{\prime}$ S $39^{\circ} 20^{\prime}$ W, 09.II.1985, fl. And fr., A.L. Gentry \& E. Zardini 49962 (MO).

\section{Jacaranda puberula Cham. Linnaea, 7: 550, 1832. Figure 5 n.}

Tree, $8 \mathrm{~m}$; branchlets cylindrical, striated, with lenticels, pubescent, with simple trichomes. Leaves bipinnate; petiole 4.6-5.8 cm long, pubescent, with simple trichomes; pinnules sessile, chartaceous, $1.8-5.5 \times 1.0-2.7 \mathrm{~cm}$, obovate to elliptic, base cuneate, apex rounded to attenuate, margin entire to irregulary serrate, slightly discolorous, adaxial surface glabrous, abaxial surface densely pubescent, with simple trichomes; venation brochidodromous. Inflorescence terminal; bracts and bracteoles ca. $0.2 \mathrm{~cm}$ long, lanceolate. Calyx $0.6-1.8 \times 0.3-0.7$ $\mathrm{cm}, 5$-dentate, teeth cuneate, purple, sparsely pubescent, with simple trichomes. Corolla $4.4-6.3 \times 0.8-1.1 \mathrm{~cm}$, lilac, externally pubescent, with glandular and simple trichomes; anthers ca. $0.2 \mathrm{~cm}$ long, di-thecae, dorsal filaments $2.2-2.3 \mathrm{~cm}$ long, ventral filament ca. $1.9 \mathrm{~cm}$ long, staminode ca. $3.8 \mathrm{~cm}$ long; disc annular, $0.1 \times 0.2 \mathrm{~cm}$; ovary ovate, $0.2 \times 0.1 \mathrm{~cm}$, glabrous, style ca. $2.5 \mathrm{~cm}$ long, stigma ca. $0.2 \mathrm{~cm}$ long, elliptic. Fruits and seeds not seen.

Habitat and Distribution: Jacaranda puberula is widely distributed in Atlantic Forest environments, where it occurs from Argentina and Rio Grande do Sul in Brazil, to the states of Bahia, Pernambuco, and Ceará (Gentry 1992). In the study area, it was found in Atlantic Forest vegetation.

Phenology: Collected with flowers from November to January.

Taxonomic Notes: Jacaranda puberula is recognized by the sessile pinnules, with abaxial surface densely pubescent and margin entire to irregularly serrate, as well as by the calyx 5-dentate with cuneate teeth (Figure 5n). The similarity and differences with J. microcalyx are discussed within the comments of that species.

Selected Material: BRAZIL. PERNAMBUCO: Bom Conselho, Fazenda Arabari, 01.XI.1966, fl., E. Tenório 66-206 (IPA 14658); Recife, Mata de Dois Irmãos, 06.I.1953, fl., Ducke \& Andrade-Lima 149 (IPA 5524).

16. Jacaranda rugosa A.H. Gentry, Fl. Neotrop. Monogr., 25(2): 102, 1992. Figure 5 o- $p$.

Tree; branchlets cylindrical, striated, without lenticels, densely pubescent, with simple trichomes. Leaves pinnate; petiole $2.1-2.6 \mathrm{~cm}$ long, pubescent, with simple trichomes; leaflets sessile, coriaceous, 1.9-4.0 $\times 1.7-2.6 \mathrm{~cm}$, elliptic, base cuneate to obtuse, apex cuneate to rounded, margin entire and revolute, surface densely rugose, discolorous, adaxial surface pubescent, with simple and short trichomes, abaxial surface densely tomentose, with simple and long trichomes; venation brochidodromous. Inflorescence axillar; bracts and bracteoles absent. Calyx $0.5-0.7 \times 0.4-0.5$ $\mathrm{cm}, 5$-dentate, teeth cuneate to rounded, lilac, villose, with glandular and simple trichomes, persistent. Corolla 3.1-5.2 $\times 1.2-1.7 \mathrm{~cm}$, lilac with tube white, externally pubescent, with glandular trichomes; anthers ca. $0.3 \mathrm{~cm}$ long, di-thecae, dorsal filaments ca. $1.8 \mathrm{~cm}$ long, ventral filaments ca. $1.5 \mathrm{~cm}$ long staminode ca. $3.7 \mathrm{~cm}$ long; disc annular, $0.2 \times 0.2 \mathrm{~cm}$; ovary ovate, $0.2 \times 1.1 \mathrm{~cm}$, glabrous, style ca. $2.5 \mathrm{~cm}$ long, stigma ca. $0.2 \mathrm{~cm}$ long, elliptic. Capsule 3.5-5.3 × 2.2-4.2 cm, elliptic to wide-elliptic, flattened, base attenuate, apex rounded, surface pubescent, with simple trichomes, margin entire, without lenticels. Seeds $1.7 \times 0.9 \mathrm{~cm}$, elliptic.

Habitat and Distribution: Jacaranda rugosa was first described by Gentry (1992) based on a material from the National Park Vale do Catimbau in Buíque (Pernambuco). Even though materials from other Brazilian states have been identified as J. rugosa, these identifications were later shown to be erroneous. As such, J. rugosa is presumed endemic from the Caatinga of Pernambuco, where it is known from the National Park Vale do Catimbau exclusively.

Phenology: Collected with flowers from September to May, and fruits from October to January and May to June.

Taxonomic Notes: Jacaranda rugosa is recognized by the densely rugose leaflets (Figure 5p), a trait exclusive to this species in the state of Pernambuco. This species is also characterized by the calyx 5-dentate with cuneate to rounded teeth (figure 5o). The similarity and differences with $J$. jasminoides are discussed within that species comments.

Selected Material: BRAZIL. PERNAMBUCO: Buíque, Vale do Catimbau, 06.XI.2002, fr. and fr., A. Lopes \& M.J. Santos 27 (UFP 45437).

Sparattosperma Martius ex Meisner, Pl. vasc. Gen. 2: 208, 1840.

Trees. Leaves palmate, 3-5 foliolate. Inflorescence terminal, a thyrse. Calyx tubular, caducous, lepidote or glabrous; corolla campanulate to infundibuliform, white to light pink; stamens included, anthers glabrous, staminode shorter than fertile stamens. Capsule linear, margin entire, without lenticels.

Sparattosperma is represented by two species ( $S$. catingae and $S$. leucanthum), distributed from South America, both of which occur in Pernambuco (Gentry 1992).

Identification key for Sparattosperma species occurring in Pernambuco state

1. Leaves 3-foliolate; calyx bilabiate with lobes cuspidate and indument lepidote; capsule with surface lepidote, without longitudinal ribs ............................................................ S. catingae 1'. Leaves 5-foliolate; calyx 2-dentate with teeth acuminate to apiculate and glabrous; capsule with surface glabrous, with longitudinal ribs S. leucanthum

\section{Sparattosperma catingae A.H. Gentry, Fl. Neotrop. Monogr, 25(2): 115, 1992. Figure $4 n-p$.}

Tree; branchlets cylindrical, striated, with lenticels, lepidote. Leaves 3-foliolate; petiole 1.2-3.8 cm long, sparsely pubescent, with simple trichomes; petiolule $0.5-1.8 \mathrm{~cm}$ long, sparsely pubescent, with simple trichomes; leaflets chartaceous, $2.3-6.8 \times 2.0-3.2 \mathrm{~cm}$, elliptic, base rounded, apex attenuate to obtuse, margin entire, discolorous, densely lepidote on both sides; venation brochidodromous. Inflorescence terminal; bracts and bracteoles $0.3-1.5 \mathrm{~cm}$ long, foliaceous, lanceolate, 
lepidote and pubescent, with simple trichomes. Calyx $0.8-1.5 \times 0.3-0.4$ $\mathrm{cm}$, bilabiate, lobes cuspidate, densely lepidote. Corolla campanulate, $2.3-3.8 \times 0.8-1.3 \mathrm{~cm}$, with to light pink ribbed wine, externally glabrous; anthers ca. $0.2 \mathrm{~cm}$ long, dorsal filaments $1.7-1.9 \mathrm{~cm}$ long, ventral filaments $1.4-1.5 \mathrm{~cm}$ long, staminode ca. $0.2 \mathrm{~cm}$ long; disc annular; ovary sessile, oblong, $0.3 \times 0.1 \mathrm{~cm}$, with longitudinal ribs, pubescent, glandular trichomes, style $1.8-2.3 \mathrm{~cm}$ long, stigma ca. 0.2 $\mathrm{cm}$ long. Capsule $23.3 \times 0.8 \mathrm{~cm}$, slightly inflated, base obtuse, apex attenuate, surface lepidote, without longitudinal ribs. Seeds not seen.

Habitat and Distribution: Sparattosperma catingae has always been thought to be an endemic species of the Caatinga vegetation from the state of Bahia (Gentry 1992, Lohmann 2010). However, this study documented the occurrence of this species in the state of Pernambuco and in the Atlantic Forest domain, where this species was found in "Mata das Negras" within the municipality of Glória de Goitá.

Phenology: Collected with flowers in January.

Taxonomic Notes: Sparattosperma catingae differs from S. leucanthum by the 3-foliolate leaves (Figure 4n) (vs. 5-foliolate in S. leucanthum; Figure 4b), bilabiate calyx with cuspidate lobes (Figure 4o) and densely lepidote (vs. 2-dentate calyx with acuminate to apiculate teeth and glabrous; Figure 6a), and fruit with lepidote surface, without longitudinal ribs (Figure 4p) (vs. capsule with glabrous surface and with longitudinal ribs; Figure 6c).

Examined Material: BRAZIL. PERNAMBUCO: Glória de Goitá, Mata das Negras, 27.I.2012, fl., L.L.S. Melo \& V.F. Silva 10 (HUEFS 191800).

Additional Examined Material: BRAZIL. BAHIA: Jequié, Fazenda Brejo Novo, 1356'41'S 4006'33,9”'W, 750 m, 30.IV.2004, fr., G.E.L. Macedo 853 (PEUFR 48828); Boa Nova, 23.III.2013, fl. and fr., A.F.P. Machado et al. 1218 (HUEFS 193968).

\section{Sparattosperma leucanthum (Vell.) K. Schum, Nat. Pflanzenfam. [Engler \& Prantl], 4(3b): 235, 1894. Figure 6 a-c.}

Tree; branchlets cylindrical, striated, with lenticels, glabrous. Leaves 5-foliolate; petiole $3.2-9.3 \mathrm{~cm}$ long, sparsely pubescent, with simple trichomes; petiolule $0.9-3.3 \mathrm{~cm}$ long, sparsely pubescent, with simple trichomes; leaflets chartaceous, $5.5-8.9 \times 1.5-4.8 \mathrm{~cm}$, elliptic, base obtuse, apex attenuate to acuminate, margin entire, discolorous, glabrous on both sides, only with simple trichomes on axils of second veins; venation brochidodromous. Inflorescence terminal; bracts and bracteoles 0.2-2.1 $\mathrm{cm}$ long, foliaceous, lanceolate, pubescent, with glandular and simple trichomes. Calyx $1.1-3.0 \times 0.3-0.7 \mathrm{~cm}, 2-$ dentate, teeth acuminate to apiculate, glabrous. Corolla infundibuliform, $2.2-5.0 \times 0.5-0.9 \mathrm{~cm}$, with to light pink ribbed wine, externally glabrous; anthers ca. $0.2 \mathrm{~cm}$ long, dorsal filaments $1.7-1.8 \mathrm{~cm}$ long, ventral filaments $1.3-1.4 \mathrm{~cm}$ long, staminode ca. $0.2 \mathrm{~cm}$ long; disc annular; ovary sessile, oblong to ovate, $0.3 \times 0.1 \mathrm{~cm}$, with longitudinal ribs, pubescent, glandular trichomes, style $2.0-2.7 \mathrm{~cm}$ long, stigma ca. $0.4 \mathrm{~cm}$ long. Capsule $23.4 \times 1.1 \mathrm{~cm}$, flattened, base obtuse, apex attenuate, surface glabrous, with longitudinal ribs. Seeds not seen.

Habitat and Distribution: Sparattosperma leucanthum is widely distributed from Venezuela and Peru to Southeastern Brazil, where it occurs in the Amazon, Caatinga, Cerrado, Atlantic Forest, and Pantanal (Gentry 1992, Lohmann 2010). In the state of Pernambuco it was found growing on roadside, in Caatinga.
Phenology: Collected with flowers in October.

Taxonomic Notes: Sparattosperma leucanthum is morphologically close to the other species of the genus, being differentiated mainly by the number of leaflets (Figure 6b), shape, calyx indument, and fruit surface (Figure 6c) (see S. catingae).

Examined Material: BRAZIL. PERNAMBUCO: Canhotinho, 07.X.1956, fl., Andrade-Lima 56-2600 (IPA 11021).

Additional Examined Material: BRAZIL. BAHIA: Cravolândia, 30.V.1994, F. França et al. 1053 (HUEFS 16945); Nova Viçosa, Argolo, 20.VII.1988, fr., G. Hatschbach \& M. Hatschbach 52260 (MO).

Tabebuia Gomes ex A. P. de Candolle, Biblioth. Universelle Genève, ser. 2, 17: 139, 1838.

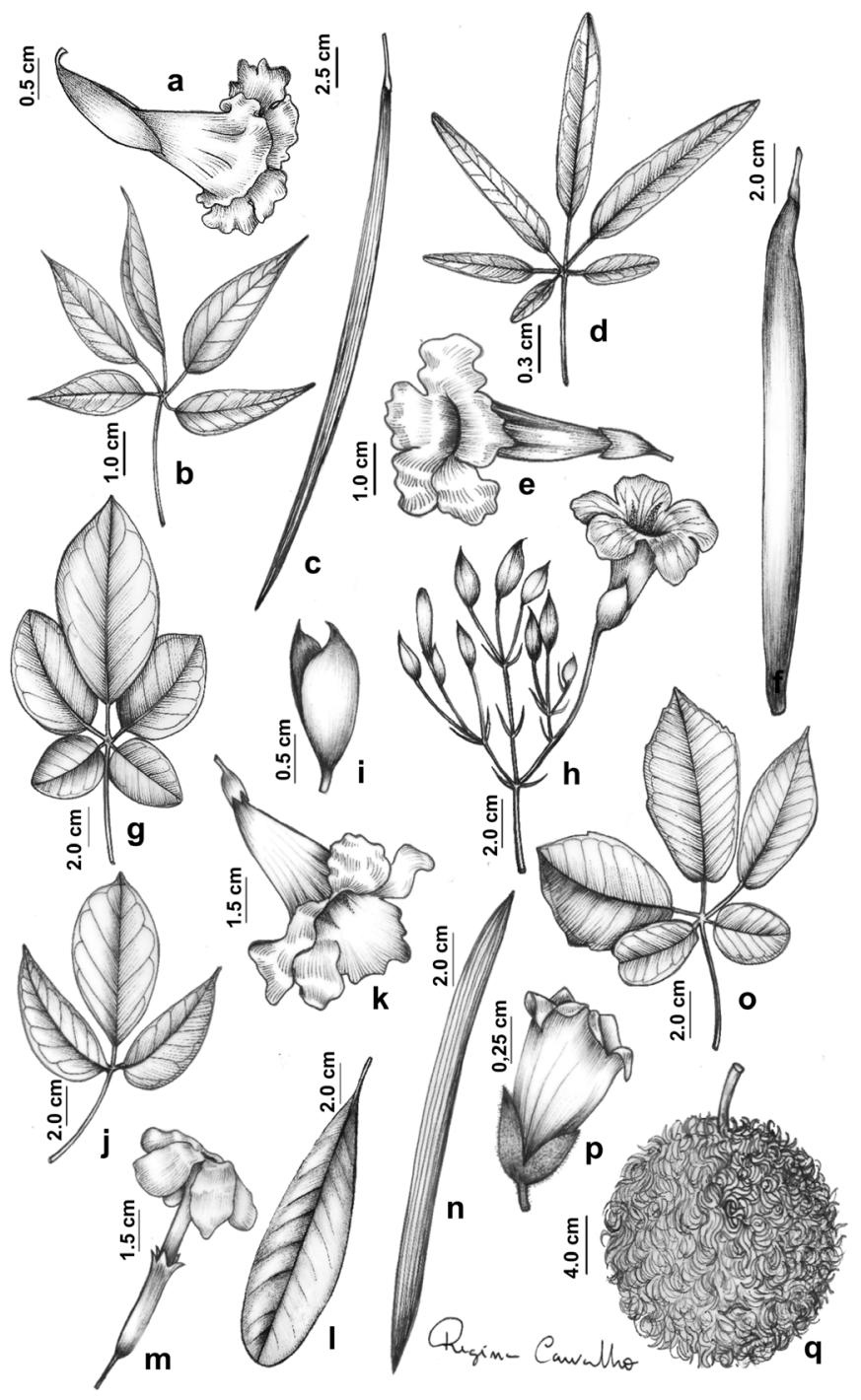

Figure 6. Sparattosperma leucanthum (Vell.) K. Schum: a. Flower. b. Leaf. c. Fruit. Tabebuia aurea (Silva Manso) Benth. \& Hook f. ex S. Moore: d. Leaf. e. Flower. f. Fruit. Tabebuia elliptica (DC.) Sandwith: g. Leaf. h. Inflorescence. i. Calyx. Tabebuia roseoalba (Ridl.) Sandwith: j. Leave. k. Flower. Tabebuia stenocalyx Sprague \& Stapf: I. Leaf. m. Flower. n. Fruit. Zeyheria tuberculosa (Vell.) Bureau ex Verl.: o. Leaf. p. Flower. q. Fruit. 
Trees. Leaves simple or palmate, 3-6 foliolate. Inflorescence terminal, a panicle. Calyx tubular, coriaceous, lepidote; corolla infundibuliform or hipocrateriform, yellow or white; stamens included, anthers glabrous, staminode shorter than fertile stamens, ovary linear. Capsule linear, flattened or inflated. Seeds winged, wings hyaline, membranaceous.

Tabebuia includes 67 species that are widely distributed from Central and South America and Antilles (Gentry 1992). In Brazil, 15 species (5 endemic) are found (Lohmann 2010). Four species were documented in the state of Pernambuco: T. aurea, T. elliptica, T. roseoalba and T. stenocalyx.

\section{Identification key for Tabebuia species occurring in the state of Pernambuco}

1. Simple leaves; corolla hipocrateriform ........................ T. stenocalyx

1'. Palmate leaves, 3-6 foliolate; corolla infundibuliform ................ 2

2. Corolla yellow; bracts and bracteoles absent; capsules wide with calyx caducous ............................................................ T. aurea

2'. Corolla white; bracts and bracteoles present; capsule narrow with calyx persistent

3. Leaves 5-foliolate; bracts and bracteoles filiform ............ T. elliptica

3'. Leaves 3-foliolate; bracts and bracteoles triangular ......... T. roseoalba

19. Tabebuia aurea (Silva Manso) Benth. \& Hookf. ex S. Moore, Trans. Linn. Soc. London, Bot., 4: 423, 1895. Figure $6 d-f$.

Tree, 3-10 m; branchlets cylindrical, striated, with lenticels, glabrous. Leaves palmate, 5-6 foliolate; petiole $1.4-8.7 \mathrm{~cm}$ long, glabrous; petiolule $1.0-4.4 \mathrm{~cm}$ long, glabrous; leaflets coriaceous, $5.3-22.3 \times 0.5-9.1 \mathrm{~cm}$, elliptic, oblong-elliptic or lanceolate, base rounded to obtuse, apex rounded to cuneate, margin entire, concolorous, glabrescent to lepidote on both sides; venation brochidodromous. Inflorescence a panicle; bracts and bracteoles absent. Calyx 0.8-1.7 $\times 0.5-0.7 \mathrm{~cm}$, irregulary dentate, teeth cuneate, light brown to yellow, densely lepidote, with sparsely distributed glands, caducous. Corolla infundibuliform, 4.3-8.1 × 1.1-1.7 cm, yellow, externally glabrous; anthers ca. $0.3 \mathrm{~cm}$ long, dorsal filaments $1.9-2.1 \mathrm{~cm}$ long, ventral filaments $1.6-1.7 \mathrm{~cm}$ long, staminode ca. $0.3 \mathrm{~cm}$ long; ovary $0.3 \times 0.1$ $\mathrm{cm}$, densely lepidote, style $2.8-3.0 \mathrm{~cm}$ long, stigma ca. $0.2 \mathrm{~cm}$ long. Capsule 10.3-20.3 × 1.7-3.7 cm, flattened, base attenuate, apex acute, surface densely lepidote, margin entire, without lenticels. Seeds 1.7-1.9 $\times 3.5-4.1 \mathrm{~cm}$, oblong-elliptic.

Habitat and Distribution: Tabebuia aurea is widely distributed in South America, occurring in dry forests and savannas of Argentina, western Bolivia, and occurring disjunctly in southern Suriname (Gentry 1992). In Brazil it is found in all phytogeographical domains extending from the Amazon to Paraná (Lohmann 2010). Due to its exuberant yellow tree-top while flowering, it is widely used in public ornamentation and landscaping. In the state of Pernambuco it is found in Caatinga environments, with altitudes varying from $300-500 \mathrm{~m}$.

Phenology: Collected with flowers from September to March, and fruits from October to December.

Taxonomic Notes: Tabebuia aurea is easily recognized by the yellow corollas (the only species of Tabebuia in Pernambuco with this character), calyx densely lepidote, with sparse glands, and wide variation in leaf shape (Figure 6e).
Selected Material: BRAZIL. PERNAMBUCO: Águas Belas, Território Indígena Fulni-ô, 01.X.2015, fl., W. Torres et al 213 (IPA 91002); Floresta, Riacho Caraíbas, 0843'09'S 38²9'39,39'W, 354 m, 11.X.2012, fl. and fr. A.C.P. Oliveira \& N.M. Almeira 1979 (HVASF 18529).

\section{Tabebuia elliptica (DC.) Sandwith, Candollea, 7: 253, 1937.} Figure $6 \mathrm{~g}-i$.

Tree, 4-5 m; branchlets cylindrical, striated, with lenticels, glabrous. Leaves palmate, 5-foliolate; petiole $1.5-10.2 \mathrm{~cm}$ long, sparsely pubescent, with simple trichomes; petiolule $0.6-2.5 \mathrm{~cm}$ long, sparsely pubescent, with simple trichomes; leaflets coriaceous, 3.3-11.2 $\times$ 2.8-7.1 cm, elliptic to oblong-elliptic, base rounded to truncate, apex acuminate to cuspidate, margin entire, concolorous, lepidote on both sides; venation brochidodromous. Inflorescence a panicle; bracts and bracteoles $0.5-1.9 \mathrm{~cm}$ long, filiform. Calyx $1.1-2.3 \times 0.4-1.0 \mathrm{~cm}, 2-3$ lobed, lobes acuminate, green, densely lepidote, persistent. Corolla infundibuliform, 4.3-7.2 × 1.2-1.7 cm, white, internally yellow and white tube, externally glabrous; anthers ca. $0.3 \mathrm{~cm}$ long, dorsal filaments $1.6-1.7 \mathrm{~cm}$ long, ventral filaments $1.4-1.5 \mathrm{~cm}$ long, staminode ca. 0.3 cm long; disc annular; ovary $0.4 \times 0.1 \mathrm{~cm}$, lepidote, style $2.1-3.2 \mathrm{~cm}$ long, stigma ca. $0.2 \mathrm{~cm}$ long. Capsule $8.7-20.9 \times 0.3-0.7 \mathrm{~cm}$, flattened, base and apex acute, glabrous, with longitudinal ribs, margin entire, without lenticels. Seeds $0.5-1.4 \times 0.4-0.5 \mathrm{~cm}$, oblong-elliptic.

Habitat and Distribution: Tabebuia elliptica is endemic to Brazil, where it occurs in "restingas" and Atlantic Forest vegetation, from Paraíba to Espirito Santo (Lohmann 2010). In Pernambuco it was found in the Atlantic Forest.

Phenology: Collected with flowers from December to March, and fruits in December.

Taxonomic Notes: Tabebuia elliptica is morphologically similar to T. roseoalba, with which it shares the cylindrical branchlets, leaflets that are concolour, elliptic to oblong-elliptic, with entire margins (Figure $6 \mathrm{~g}$ and $6 \mathrm{j}$ ), infundibuliform and glabrous corollas (Figure $6 \mathrm{~h}$ and $6 \mathrm{k}$ ). These species are distinguished by the leaves 5 -foliolate (Figure 6g) (vs. 3-foliolate in T. roseoalba (Figure 6j), bracts and bracteoles filiform (Figure 6h) (vs. triangular and numerous bracts and bracteoles), calyx 2-3 lobed acuminate (Figure 6i) (vs. irregulary lobed with cuneate lobes (Figure 6k), and corolla white externally, with yellow internally and white tube (vs. white externally, yellow internally and pink tube).

Selected Material: BRAZIL. PERNAMBUCO: Aldeia, 17.III.1952, fl., D. Andrade-Lima 52-1006 (IPA 2488); Goiana, 28.XII.1965, fl. and fr., D. Andrade-Lima 65-4344 (IPA 13709).

\section{Tabebuia roseoalba (Ridl.) Sandwith, Kew Bull., 9: 597, 1955. Figure $6 j-k$.}

Tree, $8-10 \mathrm{~m}$; branchlets cylindrical, striated, with lenticels, glabrous. Leaves palmate, 3-foliolate; petiole $1.3-10.3 \mathrm{~cm}$ long, glabrous; petiolule 0.3-2.9 cm long, glabrous; leaflets chartaceous, 3.4-11.2 × 1.5-9.1 cm, elliptic to oblong-elliptic, base obtuse to cuneate, apex acuminate, margin entire, concolorous, glabrous on both sides; venation brochidodromous. Inflorescence a panicle; bracts and bracteoles $0.3-0.7 \mathrm{~cm}$ long, triangular, numerous. 
Calyx $0.8-2.3 \times 0.3-0.7 \mathrm{~cm}$, irregulary lobed, lobes cuneate, brown, densely lepidote, persistent. Corolla infundibuliform, 2.9-6.1 ×0.5-1.3 $\mathrm{cm}$, white, internally yellow and pink tube, externally glabrous; anthers ca. $0.3 \mathrm{~cm}$ long, dorsal filaments $1.5-1.6 \mathrm{~cm}$ long, ventral filaments $1.3-1.4 \mathrm{~cm}$ long, staminode ca. $0.2 \mathrm{~cm}$ long; disc annular; ovary $0.4 \times$ $0.1 \mathrm{~cm}$, densely lepidote, style $2.4-2.7 \mathrm{~cm}$ long, stigma ca. $0.2 \mathrm{~cm}$ long. Capsule 13.2-28.8 $\times 0.3-0.7 \mathrm{~cm}$, flattened, base obtuse, apex acute, lepidote, margin entire, without lenticels. Seeds $0.4-0.5 \times 0.2-0.3 \mathrm{~cm}$, oblong-elliptic.

Habitat and Distribution: Tabebuia roseoalba occurs in dry forests of Paraguay, Bolivia, and disjunctly in Peru (Gentry 1992). In Brazil, it is distributed through most of the national territory (except the southern region), in the areas of Caatinga, Cerrado, and Atlantic Forest vegetation (Lohmann 2010). In the state of Pernambuco it occurs in the Atlantic Forest domain.

Phenology: Collected with flowers from November to June, and with fruits in January and February.

Taxonomic Notes: Tabebuia roseoalba can be recognized by the leaves 3-foliolate (Figure 6j), triangular and numerous bracts and bracteoles, and calyx irregulary lobed with cuneate lobes (Figure 6k). This species is morphologically similar to T. elliptica. The similarities and differences among those species are discussed under that species comments.

Selected Material: BRAZIL. PERNAMBUCO: Ipojuca, Sítio Oiteiro, 26.V.2012, fl., M.C. Moraes s.n. (IPA 88620); Olinda, São Bento, 01.I.1915, fl. and fr., B. Pickel 434 (IPA 4928).

\section{Tabebuia stenocalyx Sprague \& Stapf, Bull. Misc. Inform. Kew, 1910: 196, 1910. Figure $6 l-n$.}

Tree; branchlets cylindrical, striated, with lenticels, glabrous. Leaves simple; petiole $0.3-3.2 \mathrm{~cm}$ long, glabrous; leaves coriaceous, $12.1-23.3 \times 2.9-9.1 \mathrm{~cm}$, obovate to oblong-obovate, base attenuate, apex cuneate to attenuate, margin entire, concolorous, lepidote on both sides; venation brochidodromous. Inflorescence a panicle; bracts and bracteoles $0.5-0.9 \mathrm{~cm}$ long, filiform. Calyx $1.5-4.7 \times 0.3-0.6 \mathrm{~cm}$, 5-dentate, teeth acute to cuneate, green, densely lepidote with sparse glands, persistent. Corolla hipocrateriform, 7.2-8.5 $\times 0.3-0.7 \mathrm{~cm}$, white, externally glabrous; anthers ca. $0.3 \mathrm{~cm}$ long, dorsal filaments ca. $1.1 \mathrm{~cm}$ long, ventral filaments ca. $0.8 \mathrm{~cm}$ long, staminode ca. 0.3 cm long; disc cupular; ovary $0.5 \times 0.1 \mathrm{~cm}$, densely lepidote, style ca. $1.2 \mathrm{~cm}$ long, stigma ca. $0.2 \mathrm{~cm}$ long. Capsule $10.8-15.3 \times 0.7-1.0 \mathrm{~cm}$, inflated, base and apex cuneate, glabrous, with longitudinal ribs, margin entire. Seeds not seen.

Habitat and Distribution: Tabebuia stenocalyx is found in wet areas of the Guyana, Venezuela, and Brazil, where it occurs in the Atlantic Forest of Bahia, Espirito Santo, and Rio de Janeiro (Gentry 1992, Lohmann 2010). This species represents a new record for Pernambuco, where it is found in Atlantic Forest vegetation.

Phenology: Collected with flowers in September and December, and fruits in February.

Taxonomic Notes: Tabebuia stenocalyx is often confused with $T$. obtusifolia, with which it shares simple obovate to oblong-obovate leaves (Figure 61). However, these species can be separated by the long (> 7.2), 5-dentate tubular calyx (Figure 6m) (vs. campanulate and bilabiate calyx in T. obtusifolia), and corolla hipocrateriform (Figure $7 \mathrm{~m}$ ) (vs. corolla infundibuliform).
Selected Material: BRAZIL. PERNAMBUCO: Recife, Beberibe, IX.1937, fl., Vasconcelos-Sobrinho s.n. (IPA 542); Recife, Dois Irmãos, 14.II.1952, fr., D. Andrade-Lima 52-979 (IPA 2450).

\section{Zeyheria Martius, Nov. gen. Spec. pl.}

The genus includes two species (Z. montana and Z. tuberculosa) distributed in Bolivia and Brazil (Gentry 1992). In Pernambuco it is represented by Zeyheria tuberculosa.

\section{Zeyheria tuberculosa (Vell.) Bureau ex Verl., Vidensk. Meddel. Dansk Natuhist. Foren. Kjøbenhavn, 1863: 115, 1863. \\ Figure $60-q$.}

Tree or shrubs; branchlets subtetragonal, striated, without lenticels, densely tomentose, with stellate trichomes. Leaves palmate 5-foliolate; petiole $5.6-18.2 \mathrm{~cm}$ long, densely tomentose, with stellate trichomes; petiolule $0.2-0.6 \mathrm{~cm}$ long, densely tomentose, with stellate trichomes; leaflets chartaceous, $3.4-16.7 \times 2.1-6.3 \mathrm{~cm}$, elliptic to obovate, base truncate or cordate, apex acuminate, margin entire, rarely irregulary serrated, strongly discolorous, densely tomentose on both sides, with stellate and dendritic trichomes, adaxial surface dark green, rugose, abaxial surface whitish; venation brochidodromous. Inflorescence a panicle, terminal; bracts and bracteoles $1.1-2.7 \mathrm{~cm}$ long, narrowelliptics. Calyx cupular, $0.3-0.5 \times 0.3-0.4 \mathrm{~cm}$, bilabiate to truncate, lobes rounded, dark brown, densely tomentose, with stellate trichomes, caducous. Corolla wide-campanulate, $1.1-1.6 \times 0.7-1.0 \mathrm{~cm}$, externally brown, internally orange, externally densely tomentose, with stellate trichomes; stamens exserted, anthers ca. $0.1 \mathrm{~cm}$ long, glabrous, dorsal filaments $0.9-1.0 \mathrm{~cm}$ long, ventral filaments $0.8-0.9 \mathrm{~cm}$ long, staminode shorter than fertile stamens, ca. $0.2 \mathrm{~cm}$ long; ovary stipitate, obovate, 0.2 $\times 0.2 \mathrm{~cm}$, pubescent, stellate trichomes, style $0.9-1.0 \mathrm{~cm}$ long, stigma ca. $0.2 \mathrm{~cm}$ long. Capsule $8.3-12.5 \times 8.1-12.3 \mathrm{~cm}$, wide-elliptic, inflated, base and apex rounded, muricate, without lenticels. Seeds not seen.

Habitat and Distribution: Zeyheria tuberculosa occurs in all states of Northeastern and Southeastern Brazil, growing disjunctly in Bolivia in areas of Caatinga, Cerrado, and Atlantic Forest (Gentry 1992). In Pernambuco it was found growing in Atlantic Forest vegetation, growing up to $1100 \mathrm{~m}$.

Phenology: Collected with flowers from April to July, and fruits in February.

Taxonomic Notes: Zeyheria tuberculosa can be easily recognized by the strongly discolorous 5-foliolate leaves (Figure 6o), corolla widecampanulate (Figure 6p), brown externally and orange internally, and the wide-elliptic fruit with muricate surface (typical of the genus; Figure 6q). This species is commonly known as "ipê felpudo" or "bolsa de pastor." Selected Material: BRAZIL. PERNAMBUCO: Lagoa dos Gatos, Serra do Ururbu, 22.II.2011, fr., F. Gadelha 10 (HUFRN 15835); Arcoverde, Serra do Mimoso, 20.IV.1996, fl., A.M. Miranda et al. 2349 (HUEFS 97160).

\section{Discussion}

In this study we documented 23 species of the Tabebuia alliance and tribe Jacarandeae in Pernambuco, distributed among seven genera, i.e., Cybistax, Godmania, Jacaranda, Handroanthus, Sparattosperma, Tabebuia, and Zeyheria. Of these, Handroanthus (8 spp.), Jacaranda (6 spp.), Tabebuia (4 spp.), and Sparattosperma (2 spp.) are the most diverse. 
The genera Cybistax, Godmania, and Zeyheria are represented by a single species each (Table 1). The most frequent species in the area are: Handroanthus impetiginosus (Mart. ex DC.) Mattos and Tabebuia aurea (Silva Manso) Benth. \& Hook f. ex S. Moore.

In the checklist of the Bignoniaceae from Brazil, Lohmann (2010) documented 16 species of the Tabebuia alliance and tribe Jacarandeae for the state of Pernambuco. The occurrence of all of these taxa in Pernambuco was confirmed during this study. Besides those, Cybistax antisyphilitica (Mart.) Mart., Handroanthus capitatus (Bureau \& K. Schum) Mattos, Handroanthus umbellatus (Sond.) Mattos, Jacaranda cuspidifolia Mart., Sparattosperma catingae A.H. Gentry, and Tabebuia stenocalyx Sprague \& Stapf were documented for the first time in the state of Pernambuco, thus constituting new records.

Furthermore, S. catingae, previously thought to be endemic to the Caatinga of Bahia, was documented for the first time in the Atlantic Forest domain (Table 1). Jacaranda cuspidifolia was also documented for the first time in Northeastern Brazil. In addition, Jacaranda rugosa was confirmed as an endemic species of Pernambuco caatinga, being found only in the National Park Vale do Catimbau (see the comments of this species).

The diversity map (Figure 2) indicated that the State Park Dois Irmãos (Figure 2f), the National Park Vale do Catimbau (Figure 2d), Ecological Reserve Carnijó (Figure 2e), and the National Forest Negreiros (Figure 2a) represent the three most diverse areas in the state of Pernambuco. These areas are located within conservation units, highlighting the importance of these units for species preservation. The diversity map also highlights other priority areas for conservation within the state, all of which include high diversity but are outside of conservation units, such as Triunfo (Figure 2c) and Petrolina (Figure 2b).

\section{Supplementary material}

The following online material is available for this article:

Appendix 1 - List of examined materials

\section{Acknowledgments}

The authors thank the managers of the conservation units visited during fieldwork, ICMBIO for collecting permits, and herbarium curators and technicians for allowing us to examine their collections. We also thank the Conselho Nacional de Desenvolvimento Científico e Tecnológico (CNPq) for a Masters scholarship to SLC and a Pq-1B grant to LGL (310871/2017-4). We also thank the Federal Rural University of Pernambuco for supporting this study, Regina Carvalho for preparing the botanical illustrations, and Silmara Nepomuceno and Thaís Mara Souza for preparing the maps.

\section{Author Contributions}

Swami Costa: Data collection; species identification; data analysis and interpretation; manuscript preparation; and, study design.

Lúcia G. Lohmann: Data interpretation; species identification; manuscript preparation and critical revision, adding intellectual content.

Maria Teresa Buril: Data collection; manuscript preparation and critical revision, adding intellectual content; and study design.

\section{Conflict of interest}

The authors declare that they have no conflict of interest related to the publication of this manuscript.

\section{References}

ANDRADE-LIMA, D. 1960. Estudos fitogeográficos de Pernambuco. Arq. Inst. Pesqui. Agron. (5): 305-341.

BRIDSON, D. \& FORMANN, L. 1998. The herbarium handbook. 3 ed. Royal Botanic Gardens, Kew.

BRITO, I.J.N., COSTA, S.L., CORDEIRO, J.M.P., LOHMANN, L.G. \& MELO, J.I.M. 2018. New records of the Tabebuia Alliance (Bignoniaceae) for the state of Paraíba, northeastern Brazil. Rev Mex Biodivers. 89(3): 625-630.

BUREAU, I.E. \& SCHUMANN, K. 1896. Bignoniaceae. In: Flora Brasiliensis (C.F.P Martius \& A.G. Eichler, eds.). F. Fleischer. v. 8, n. 2. p. $2-298$

ESPÍRITO-SANTO, F.S., SILVA-CASTRO, M.M. \& RAPINI, A. 2013. Flora da Bahia: Bignoniaceae 2 - Aliança Tabebuia (Bignoniaceae). Sitientibus Ser. cienc. biol., 13: 1-38.

GENTRY, A.H. 1980. Bignoniaceae, Part I. Tribes Crescentieae and Tourrettieae. Flora Neotropica Monograph v. 25, p. 1-130.

GENTRY, A.H. 1992. Bignoniaceae Part II - Tribe Tecomeae. Flora Neotropica. New York, v. 25, p. 1-362.

GENTRY, A.H. 2009. Bignoniaceae, Flora de Colombia. Universidad Nacional de Colombia. n. 25, 462p.

GONÇALVES, E.G. \&LORENZI, H. 2007. Morfologia Vegetal - Organografia e Dicionário Ilustrado de Morfologia das Plantas Vasculares. Nova Odessa: Plantarum.

GROSE, S.O. \& OLMSTEAD, R.G. 2007. Evolution of a charismatic neotropical tree: molecular phylogeny of Tabebuia s. 1., and allied genera (Bignoniaceae). Syst Bot 32: 650-659.

HARRIS, J.G. \& HARRIS, M.W. 1994. Plant identification terminology: an illustrated glossary. Utah, Spring Lake. 198p.

LOHMANN, L.G. 2004. Bignoniaceae In: Flowering Plants of the Neotropics (N. Smith, S.A. Mori, A. Henderson, D.W. Stevenson \& S.V. Heald eds.). New Jersey: Princeton University Press. p. 51-53.

LOHMANN, L.G. 2010. Bignoniaceae in Flora do Brasil 2020 em construção. Jardim Botânico do Rio de Janeiro <http://floradobrasil.jbrj.gov.br/reflora/ floradobrasil/FB112305> (last acess 01/11/2018)

LOHMANN, L.G. \& PIRANI, J.R. 1996a. Tecomeae: Bignoniaceae da Cadeia do Espinhaço, Minas Gerais e Bahia, Brasil. Acta Bot Bras 10: 103-137.

LOHMANN, L.G. \& PIRANI J.R. 1996b. Flora da Serra do Cipó, Minas Gerais, Brasil: Bignoniaceae. Bol Bot Univ São Paulo 17: 127-153.

LOHMANN, L.G. \& PIRANI, J.R. 2003. Flora de Grão-Mogol, Minas Gerais: Bignoniaceae. Bol Bot Univ São Paulo 21: 109-121.

LOHMANN, L.G. \& ULLOA ULLOA, C. [2006, continuously updated]. Bignoniaceae. In: iPlants prototype checklist. http://www.iplants.org (last acess $10 / 08 / 2011$ )

OLMSTEAD, R.G., ZJHRA, M.L., LOHMANN L.G., GROSE, S.O. \& ECKERT, A.J. 2009. A molecular phylogeny and classification of Bignoniaceae. Am J Bot 96: 1731-1743.

PEREIRA, P.H. \& MANSANO, V.F. 2008. Estudos taxonômicos da tribo Tecomeae (BIGNONIACEAE) no Parque Nacional do Itatiaia, Brasil. Rodriguésia. Rio de Janeiro, 59(2): 265-289.

SCUDELLER, V.V. 2004. Bignoniaceae Juss. no Parque Nacional da Serra da Canastra, Minas Gerais, Brasil. Iheringia, Sér Bot 59: 59-73.

SILVA-CASTRO, M.M., COSTA, C.R.A. \& BRITO, R.F. 2007. Flora da Bahia - Bignoniaceae I: Jacaranda Jussieu. Sitientibus Ser. cienc. biol., 7: 15-31.

SPANGLER, R.E. \& OLMSTEAD, R.G. 1999. Phylogenetic analysis of Bignoniaceae based on the cpDNA gene sequences rbcL and ndhF. Ann Mo Bot Gard 86: 33-46. 
COSTA, S, et al.

THIERS, B. [Continuously updated]. Index Herbariorum: a global directory of

Received: $23 / 03 / 2019$ public herbaria and associated staff. New York Botanical Garden's Virtual

Accepted: 19/08/2019

Herbarium. http://sweetgum.nybg.org/ih/ (last acess 4/02/2012).

Published online: 03/10/2019 